\title{
RNA Regulators in Leukemia and Lymphoma
}

\author{
Camila Prieto and Michael G. Kharas \\ Molecular Pharmacology Program, Memorial Sloan Kettering Cancer Center, New York, New York 10065, USA \\ Correspondence: kharasm@mskcc.org
}

Posttranscriptional regulation of mRNA is a powerful and tightly controlled process in which cells command the integrity, diversity, and abundance of their protein products. RNAbinding proteins (RBPs) are the principal players that control many intermediary steps of posttranscriptional regulation. Recent advances in this field have discovered the importance of RBPs in hematological diseases. Herein we will review a number of RBPs that have been determined to play critical functions in leukemia and lymphoma. Furthermore, we will discuss the potential therapeutic strategies that are currently being studied to specifically target RBPs in these diseases.

$T^{1}$ he integrity, diversity, and abundance of the cell's protein products are largely controlled through posttranscriptional regulation, consisting of many intermediary steps between transcription and translation. This highly coordinated process includes nascent RNAs undergoing alternative splicing, editing, polyadenylation, capping, $3^{\prime}$ end formation, and nucleocytoplasmic transport to the ribosome before being translated and ultimately degraded (Hong 2017; Pereira et al. 2017). Posttranscriptional regulation is primarily controlled by RNA-binding proteins (RBPs) and small RNAs that predominantly bind to specific elements located in the untranslated regions (UTRs) of target mRNAs.

Large-scale quantitative methods have revealed at least 1500 distinct eukaryotic RBPs belonging to a variety of functional families and with the ability to bind and regulate thousands of transcripts (Gerstberger et al. 2014). This diversity seems to have increased during evolution in correlation with the rise in the number of introns (Glisovic et al. 2008). RBPs bind to specific mRNA sequences or structures to recruit and form functional complexes with other molecules to modulate gene expression (Table 1). These dynamic ribonucleoprotein (RNP) complexes dictate how the transcript is processed, where it is localized, and if or when it is translated.

The first step of posttranscriptional regulation occurs when these RNP complexes are formed in the nucleus as transcription progresses. Alternative splicing, the process in which introns are removed from the pre-mRNA and the remaining exons are ligated, is carried out by the spliceosome. The spliceosome is a macromolecule complex consisting of five small nuclear ribonucleoproteins (snRNPs) and small nuclear RNAs, and includes the RBPs SF3B1, SRSF2, and U2AF1 (Graveley and Maniatis 1998; Schaal and Maniatis 1999; Chen and Man-

Editors: Michael G. Kharas, Ross L. Levine, and Ari M. Melnick

Additional Perspectives on Leukemia and Lymphoma: Molecular and Therapeutic Insights available at

www.perspectivesinmedicine.org

Copyright (C) 2020 Cold Spring Harbor Laboratory Press; all rights reserved; doi: 10.1101/cshperspect.a034967

Cite this article as Cold Spring Harb Perspect Med 2020;10:a034967 
C. Prieto and M.G. Kharas

Table 1. RNA-binding proteins (RBPs) have the ability to bind and regulate a myriad of transcripts

\begin{tabular}{|c|c|c|c|c|}
\hline RBP & $\begin{array}{c}\text { mRNA } \\
\text { mechanistic } \\
\text { basis }\end{array}$ & Putative targets & $\begin{array}{c}\text { Role in leukemia and } \\
\text { lymphoma }\end{array}$ & $\begin{array}{l}\text { Carcinogenic } \\
\text { potential }\end{array}$ \\
\hline $\begin{array}{l}\text { Splicing factor } 3 \\
\text { subunit b1 (SF3B1), } \\
\text { Serine arginine-rich } \\
\text { splicing factor } 2 \\
\text { (SRSF2), U2 small } \\
\text { nuclear RNA } \\
\text { auxiliary factor } 1 \\
\text { (U2AF1) }\end{array}$ & $\begin{array}{l}\text { Splicing; } \\
\text { mRNA } \\
\text { processing }\end{array}$ & $\begin{array}{l}\text { Enhancer of zeste } 2 \\
\text { Polycomb } \\
\text { repressive complex } \\
2 \text { subunit }(\mathrm{EZH} 2)\end{array}$ & $\begin{array}{l}\text { Mutated in } \\
\text { myelodysplastic } \\
\text { syndrome (MDS), } \\
\text { myeloproliferative } \\
\text { neoplasms (MPN), } \\
\text { and leukemia; } \\
\text { mutations are } \\
\text { mutually exclusive; } \\
\text { mutations in SRSF2 } \\
\text { and U2AF1 resulted } \\
\text { in elevated R loops } \\
\text { and replication } \\
\text { stress }\end{array}$ & Proto-oncogenic \\
\hline $\begin{array}{l}\text { RNA-binding motif } \\
\text { protein } 39 \text { (RBM39) }\end{array}$ & Splicing & BMI1; MYB; GATA2 & $\begin{array}{l}\text { Overexpressed in acute } \\
\text { myeloid leukemia } \\
\text { (AML); depletion } \\
\text { resulted in RNA } \\
\text { splicing changes in } \\
\text { AML }\end{array}$ & Proto-oncogenic \\
\hline $\begin{array}{l}\text { Methyltransferase-like } \\
3 \text { (METTL3) }\end{array}$ & $\begin{array}{l}\text { RNA } \\
\text { methylation } \\
\text { (m A writer) }\end{array}$ & $\begin{array}{l}\text { MYC; MYB; BCL2; } \\
\text { phosphatase and } \\
\text { tensin homolog } \\
\text { (PTEN) }\end{array}$ & $\begin{array}{l}\text { Overexpressed in } \\
\text { leukemia; depletion } \\
\text { resulted in induced } \\
\text { differentiation, } \\
\text { increased apoptosis, } \\
\text { and delayed } \\
\text { leukemogenesis in } \\
\text { vivo }\end{array}$ & Proto-oncogenic \\
\hline $\begin{array}{l}\text { RNA-binding motif } \\
\text { protein } 15(\mathrm{RBM} 15)\end{array}$ & $\begin{array}{l}\text { Splicing; } \\
\text { mRNA } \\
\text { export; RNA } \\
\text { methylation } \\
\text { (m }{ }^{6} \mathrm{~A} \\
\text { adaptor } \\
\text { protein) }\end{array}$ & $\begin{array}{l}\text { Suppressor of hairless } \\
{[\mathrm{Su}(\mathrm{H}) \text {; human }} \\
\text { homolog }(\mathrm{RBPJ}) \text {; } \\
\text { SET domain } \\
\text { containing 1B } \\
\text { protein (SETD1B) }\end{array}$ & $\begin{array}{l}\text { MKL fusion partner in } \\
\text { acute } \\
\text { megakaryoblastic } \\
\text { leukemia (AMKL); } \\
\text { AMKL in non- } \\
\text { Down syndrome } \\
\text { infants has poor } \\
\text { prognosis }\end{array}$ & Proto-oncogenic \\
\hline LIN28A & $\begin{array}{l}\text { miRNA } \\
\text { processing }\end{array}$ & let-7 family members & $\begin{array}{l}\text { Overexpression in } \\
\text { OCI-AML3 resulted } \\
\text { in cell cycle arrest } \\
\text { and differentiation }\end{array}$ & $\begin{array}{l}\text { Tumor- } \\
\text { suppressor }\end{array}$ \\
\hline LIN28B & $\begin{array}{l}\text { miRNA } \\
\text { processing }\end{array}$ & $\begin{array}{l}\text { let-7 family members; } \\
\quad \text { miR-150 }\end{array}$ & $\begin{array}{l}\text { Overexpressed in } \\
\text { peripheral T-cell } \\
\text { lymphoma (PTCL), } \\
\text { blast crisis chronic } \\
\text { myeloid leukemia } \\
\text { (BC-CML), and }\end{array}$ & Proto-oncogenic \\
\hline
\end{tabular}

Continued 
RNA Regulators in Leukemia and Lymphoma

Table 1. Continued

\begin{tabular}{|c|c|c|c|c|}
\hline RBP & $\begin{array}{c}\text { mRNA } \\
\text { mechanistic } \\
\text { basis }\end{array}$ & Putative targets & $\begin{array}{l}\text { Role in leukemia and } \\
\text { lymphoma }\end{array}$ & $\begin{array}{l}\text { Carcinogenic } \\
\text { potential }\end{array}$ \\
\hline & & & $\begin{array}{l}\text { AP-CML; } \\
\text { overexpression in } \\
\text { mice led to } \\
\text { lymphoma and } \\
\text { PTCL; promoted } \\
\text { AML cell } \\
\text { proliferation; MYC } \\
\text { up-regulated its } \\
\text { expression }\end{array}$ & \\
\hline $\begin{array}{l}\text { Human antigen } \mathrm{R} \\
\quad(\mathrm{HuR})\end{array}$ & $\begin{array}{l}\text { mRNA stability; } \\
\text { mRNA } \\
\text { translation; } \\
\text { pre-mRNA } \\
\text { processing }\end{array}$ & $\begin{array}{l}\text { Eukaryotic initiation } \\
\text { factor } 4 \mathrm{E} \text { (eIF4E) }\end{array}$ & $\begin{array}{l}\text { Overexpressed in M4 } \\
\text { AML; promoted } \\
\text { tumorigenesis }\end{array}$ & Proto-oncogenic \\
\hline eIF4E & $\begin{array}{l}\text { mRNA } \\
\text { translation by } \\
\text { binding to } 5^{\prime} \\
\text { cap; mRNA } \\
\text { transport }\end{array}$ & Cyclin D1 & $\begin{array}{l}\text { Overexpressed in M4/ } \\
\text { M5 AML and BC- } \\
\text { AML; accelerated } \\
\text { lymphomagenesis }\end{array}$ & Proto-oncogenic \\
\hline $\begin{array}{r}\text { Eukaryotic initiation } \\
\text { factor 4A (eIF4A) }\end{array}$ & $\begin{array}{l}\text { mRNA } \\
\text { translation }\end{array}$ & $\begin{array}{l}\text { MYC; MYB; } \\
\text { NOTCH; CDK6; } \\
\text { BCL2 }\end{array}$ & $\begin{array}{l}\text { Promoted T-cell acute } \\
\text { lymphoblastic } \\
\text { leukemia (T-ALL) } \\
\text { development in vivo }\end{array}$ & Proto-oncogenic \\
\hline $\begin{array}{l}\text { Insulin-like growth } \\
\text { factor } 2 \text { mRNA- } \\
\text { binding protein } 1 \\
\text { (IGF2BP1) }\end{array}$ & $\begin{array}{l}\text { mRNA stability; } \\
\text { mRNA } \\
\text { localization; } \\
\text { mRNA } \\
\text { translation }\end{array}$ & & $\begin{array}{l}\text { Overexpressed in } \\
\text { Hodgkin's } \\
\text { lymphoma, B-cell } \\
\text { lymphoma, and } \\
\text { ETV6/RUNX1- } \\
\text { positive leukemia }\end{array}$ & Proto-oncogenic \\
\hline $\begin{array}{l}\text { Insulin-like growth } \\
\text { factor } 2 \text { mRNA- } \\
\text { binding protein } 3 \\
\text { (IGF2BP3) }\end{array}$ & $\begin{array}{l}\text { mRNA stability; } \\
\text { mRNA } \\
\text { localization; } \\
\text { mRNA } \\
\text { translation }\end{array}$ & IGF2; MYC; CDK6 & $\begin{array}{l}\text { Overexpressed in } \\
\text { lymphomas, mixed- } \\
\text { lineage leukemia } \\
\text { (MLL)-AF4- } \\
\text { positive leukemia, } \\
\text { and BCR/ABL1- } \\
\text { positive acute } \\
\text { lymphoblastic } \\
\text { leukemia (ALL); } \\
\text { dysregulated in B- } \\
\text { cell acute } \\
\text { lymphoblastic } \\
\text { leukemia (B-ALL) }\end{array}$ & Proto-oncogenic \\
\hline
\end{tabular}


C. Prieto and M.G. Kharas

Table 1. Continued

\begin{tabular}{|c|c|c|c|c|}
\hline RBP & $\begin{array}{c}\text { mRNA } \\
\text { mechanistic } \\
\text { basis }\end{array}$ & Putative targets & $\begin{array}{l}\text { Role in leukemia and } \\
\text { lymphoma }\end{array}$ & $\begin{array}{l}\text { Carcinogenic } \\
\text { potential }\end{array}$ \\
\hline $\begin{array}{l}\text { Insulin-like growth } \\
\text { factor-binding } \\
\text { protein } 7 \text { (IGFBP7) }\end{array}$ & & & $\begin{array}{l}\text { Low expression } \\
\text { correlates with poor } \\
\text { prognosis in AML; } \\
\text { suppressed } \\
\text { tumorigenesis; low } \\
\text { expression in } \\
\text { leukemia stem cells } \\
\text { (LSCs) }\end{array}$ & $\begin{array}{l}\text { Tumor- } \\
\text { suppressor }\end{array}$ \\
\hline $\begin{array}{l}\text { Musashi RNA- } \\
\text { binding protein } 2 \\
\text { (MSI2) }\end{array}$ & $\begin{array}{l}\text { mRNA } \\
\text { translation }\end{array}$ & $\begin{array}{l}\text { MYC; homeobox A9 } \\
\text { (HOXA9); } \\
\text { IKAROS family } \\
\text { zinc finger } 2 \\
\text { (IKZF2); } \\
\text { Tetrespanin-3 } \\
\text { (TSPAN3); FMS- } \\
\text { like tyrosine kinase } \\
3 \text { (FLT3); } \\
\text { branched-chain } \\
\text { amino acid } \\
\text { aminotransferase } 1 \\
\text { (BCAT1) }\end{array}$ & $\begin{array}{l}\text { Fusion partner; } \\
\text { overexpressed in } \\
\text { chronic } \\
\text { lymphocytic } \\
\text { leukemia } \\
\text { (CLL), adult B-ALL, T- } \\
\text { ALL, MDS, CML, } \\
\text { and AML; required } \\
\text { for leukemia } \\
\text { progression }\end{array}$ & Proto-oncogenic \\
\hline $\begin{array}{l}\text { Synaptotagmin- } \\
\text { binding, } \\
\text { cytoplasmic RNA- } \\
\text { interacting protein } \\
\text { (SYNCRIP) }\end{array}$ & $\begin{array}{l}\text { mRNA } \\
\text { translation }\end{array}$ & HOXA9 & $\begin{array}{l}\text { Promoted } \\
\text { leukemogenesis in } \\
\text { AML; tumor } \\
\text { suppressor in } \\
\text { T-ALL with 6q } \\
\text { deletion }\end{array}$ & $\begin{array}{l}\text { Proto-oncogenic } \\
\text { and tumor- } \\
\text { suppressor }\end{array}$ \\
\hline $\begin{array}{l}\text { Heterogeneous } \\
\text { nuclear } \\
\text { ribonucleoprotein } \mathrm{K} \\
\text { (hnRNPK) }\end{array}$ & $\begin{array}{l}\text { mRNA } \\
\text { metabolism }\end{array}$ & $\begin{array}{c}\text { MYC; p21; CCAAT- } \\
\text { enhancer-binding } \\
\text { protein }(\mathrm{C} / \mathrm{EBP})\end{array}$ & $\begin{array}{l}\text { Depletion in BCR/ } \\
\text { ABL transformed } \\
\text { cells resulted in } \\
\text { impaired } \\
\text { leukemogenesis; } \\
\text { reduced expression } \\
\text { in AML patients } \\
\text { with 6q deletion; } \\
\text { Hnrnpk } \\
\text { haploinsufficient } \\
\text { mice developed a } \\
\text { myeloproliferative } \\
\text { phenotype and } \\
\text { lymphoma }\end{array}$ & $\begin{array}{l}\text { Proto-oncogenic } \\
\text { and tumor- } \\
\text { suppressor }\end{array}$ \\
\hline
\end{tabular}


RNA Regulators in Leukemia and Lymphoma

ley 2009). After splicing, the mature mRNA is further associated with RBPs and exported out of the nucleus. Upon localization to the cytoplasm, additional RBPs bind to and dictate the fate of the mRNA. Some RBPs, including human antigen $\mathrm{R}$ (HuR) and IGF2BP3, stabilize the mRNA and protect it from rapid turnover (Brennan and Steitz 2001; Bell et al. 2013; Wurth and Gebauer 2015). Other RBPs, such as Musashi RNA-binding protein 2 (MSI2), enhance the translation of their mRNA targets (Park et al. 2015). Yet other RBPs drive efficient translation, such as the heterotrimeric complex eIF4F, which consists of the subunits eIF4E, eIF4A, and eIF4G. This complex is responsible for regulating cap-dependent translation initiation by binding to the mRNA $5^{\prime}$ cap and unwinding the mRNA $5^{\prime}$ UTR secondary structure to create a binding site for ribosomes (Fig. 1; Table 1; Parsyan et al. 2011).
For the large repertoire of RBPs, one would expect an equal amount of diversity in structures with the ability to recognize mRNA. Yet, RBPs often contain one or multiple highly conserved RNA-binding domains (RBDs), consisting of 60-100 amino acids. RBDs provide specificity for the RBPs to bind to their target mRNAs and allow the functional classification of RBPs into families. Although there are more than 40 RBDs identified, some of the most wellcharacterized include RNA recognition motif (RRM), K-homology (KH) domain, RGG (ArgGly-Gly) box, Sm domain, DEAD/DEAH box, Zinc finger (ZF) domain, double stranded RNA-binding domain (dsRBD), cold-shock domain (CSD), and Piwi/Argonaute/Zwille (PAZ) domain. RBPs containing different combinations of RBDs have increased flexibility to bind numerous mRNAs with different specificities and affinities (Lunde et al. 2007; Glisovic et al. 2008; Hong

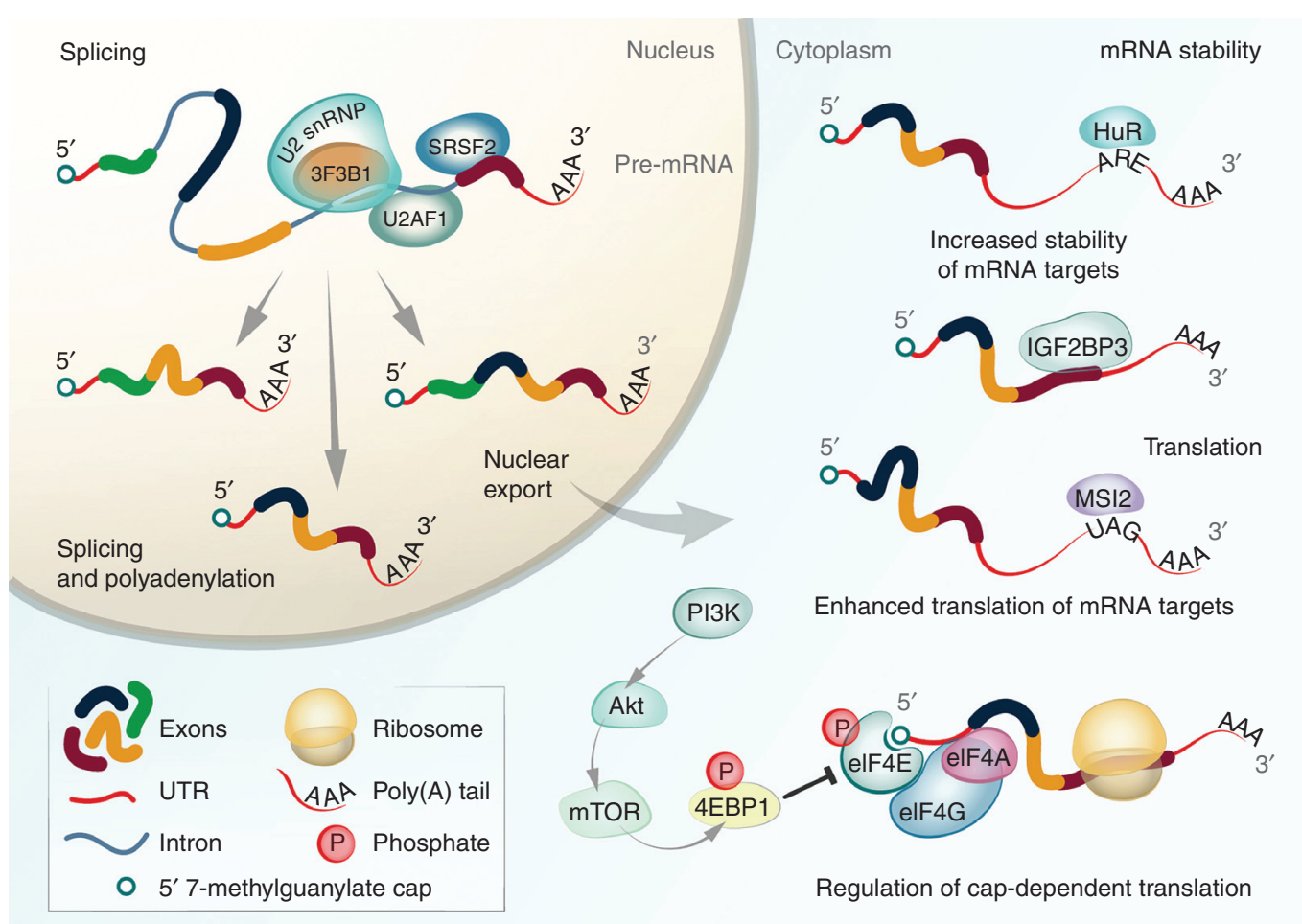

Figure 1. Overview of the main cellular stages of posttranscriptional regulation. A general pathway for several of the many intermediary steps of posttranscriptional regulation, including some RNA-binding proteins (RBPs) demonstrated to be involved in controlling these steps. The steps highlighted include splicing, nucleocytoplasmic transport, mRNA stability, and translation. 
2017). Yet, many RBPs lack these characterized RBDs and instead are composed of low complexity, intrinsically disordered regions, allowing them to associate with mRNA in a highly flexible and adaptable manner (Wurth and Gebauer 2015; Pereira et al. 2017).

With this central role in the regulation of the gene expression program, it follows that dysregulation of RBPs can lead to disease, including cancer (Lukong et al. 2008; Cooper et al. 2009; Darnell 2010). Although cytogenetic aberrations and alterations to signaling pathways have been well-studied in cancer, the mechanisms of posttranscriptional regulation have only recently come to the forefront of scientific investigation. Aberrant expression and mutations of RBPs have been reported in numerous cancer types, with several RBPs being identified as important players in leukemia and lymphoma (Kechavarzi and Janga 2014). This review will cover RNA regulators that are dysregulated in leukemia and lymphoma and explore their potential as therapeutic targets.

\section{RNA-BINDING PROTEINS IN LEUKEMIA AND LYMPHOMA}

\section{RBPs Regulating Splicing \\ Splicing Factors SF3B1, SRSF2, and U2AF1}

One of the steps integral to posttranscriptional regulation is mRNA splicing. mRNA splicing is a crucial contributor to the integrity and diversity of final protein products and is accomplished by spliceosomes. Spliceosomes are formed by five snRNPs and small nuclear RNAs. They function by removing introns from the primary transcript, the pre-mRNA, and ligating the remaining flanking exons to generate mature mRNA. Alternative splicing increases genomic diversity by altering the mRNA by using alternative $5^{\prime}$ and $3^{\prime}$ splice sites or retaining introns and unconventional exons. Because RNA splicing is very conserved in eukaryotic cells, alterations to this pathway can lead to disease, including leukemia and lymphoma (Chen and Manley 2009).

In hematological diseases, genomic studies have identified somatic mutations in many classes of genes, including splicing factors. Similar- ly, advances in exome sequencing have revealed mutations in spliceosomal genes most commonly occurring in myelodysplastic syndrome (MDS), myeloproliferative neoplasms (MPN), acute myeloid leukemia (AML), chronic lymphcytic leukemia (CLL), and chronic myelomonocytic leukemia (CMML) (Malcovati et al. 2011; Papaemmanuil et al. 2011; Wang et al. 2011; Yoshida et al. 2011; Graubert et al. 2012; Quesada et al. 2012; Visconte et al. 2012a). The most commonly mutated genes are splicing factor 3 subunit b1 (SF3B1), serine arginine-rich splicing factor 2 (SRSF2), and U2 small nuclear RNA auxiliary factor 1 (U2AF1); this review will concentrate primarily on SF3B1 and SRSF2 (Visconte et al. 2012b). Recurrent mutations in those genes are the most common genetic alterations in MDS patients. They occur as heterozygous point mutations in specific residues and are mutually exclusive with one another. However, the importance of these significant mutational occurrences and how they mechanistically contribute to tumorigenesis are just beginning to be investigated.

SF3B1, a component of the SF3B complex, is part of the U2-small nuclear ribonucleoprotein (U2snRNP) complex and responsible for binding to the exon-intron junction at the $3^{\prime}$ splice site. The SF3B1 protein consists of an aminoterminal domain involved in protein-RNA and protein-protein interactions and a carboxy-terminal region of $22 \mathrm{HEAT}$ domains (Huntingtin, elongation factor 3 , protein phosphatase $2 \mathrm{~A}$, and the yeast PI3-kinase TOR1). SF3B1 mutations were identified in $20 \%$ of patients with MDS, $19 \%$ with MDS/MPN, and 5.3\% with AML. These mutations occur most frequently in the fourth, fifth, and sixth HEAT domains and are associated with overall better survival and lower risk of evolution into AML (Malcovati et al. 2011; Papaemmanuil et al. 2011). SF3B1 mutations were also found in $81 \%$ of patients with two MDS subtypes: refractory anemia with ring sideroblasts (RAR) and refractory cytopenia with multilineage dysplasia and ring sideroblasts (RCMD-RS). These patients exhibited ring sideroblasts, mitochondrial iron deposits, and significantly better overall survival, consistent with previous literature (Visconte 
et al. 2012a; Malcovati et al. 2015). Interestingly, a $S f 3 b 1$ heterozygous knockout mice model displayed the same ring sideroblast phenotype. Additionally, SF3B1 depletion in K562 cells resulted in down-regulation of U2-type intron splicing (Visconte et al. 2012c). Contrarily, SF3B1 mutations were identified in $15 \%$ of CLL patients that exhibited more aggressive disease (Wang et al. 2011; Quesada et al. 2012).

The SRSF2 gene belongs to the serine/arginine-rich (SR) family of pre-mRNA splicing factors, contains an RRM and an arginine and serine-rich domain, and is important for constitutive and alternative splicing (Graveley and Maniatis 1998; Schaal and Maniatis 1999; Liu et al. 2000). SRSF2 mutations occur in CMML and advanced forms of MDS, and unlike SF3B1 mutations, they predict shorter survival (Yoshida et al. 2011; Makishima et al. 2012; Meggendorfer et al. 2012; Papaemmanuil et al. 2013). Conditional knockout of SRSF2 in the thymus caused a T-cell maturation defect by affecting the alternative splicing of CD45 (lymphocyte common antigen), a known receptor tyrosine phosphatase involved in thymocyte development (Wang et al. 2001).

More recently, several studies have attempted to untangle the role of these splicing factor mutations in vivo, suggesting that these mutations alter RNA splicing preferences distinct from those observed upon wild-type protein loss (Lee and Abdel-Wahab 2016). Srsf2(P95H) mice displayed multilineage dysplasia, and this Srsf2 mutation altered SRSF2's specific exonic splicing enhancer motifs recognition, leading to the missplicing and nonsense-mediated decay of the hematopoietic regulator enhancer of zeste 2 polycomb repressive complex 2 subunit (EZH2) (Kim et al. 2015; Kon et al. 2018). Sf3b1(K700E) mice developed erythroid defects, possibly because of abnormal $3^{\prime}$ splice-site selection (Obeng et al. 2016). Last, transgenic U2af1(S34F) mice exhibited altered hematopoiesis, with premRNA splicing changes in hematopoietic progenitor cells (Shirai et al. 2015). As mentioned, these mutations occur in a heterozygous manner, consistent with research demonstrating the synthetic lethality between murine $S f 3 b 1$ and Srsf 2 mutations in vivo and the necessity for a wild-type gene copy (Fei et al. 2016; Lee et al. 2016, 2018). Strikingly, each of these splicing factor mutations seems to affect splicing distinctly, yet they all cause the same phenotype. One paper noted that these mutations might all contribute to MDS via R-loop formation, in which mutations in SRSF2 and U2AF1 resulted in elevated $\mathrm{R}$ loops and replication stress (Chen et al. 2018). Despite these recent advances, questions still remain concerning whether these splicing factor mutations are the main drivers of the disease, if other converging mechanisms exist, and if synergy with other types of mutations drive disease progression.

\section{RBM39}

RNA-binding motif protein 39 (RBM39; also known as CAPER- $\alpha$ ) is a known splicing factor that has been shown to interact with other splicing factors, such as SF3B1 and U2AF65, and cause splicing changes when depleted (Imai et al. 1993; Loerch et al. 2014; Stepanyuk et al. 2016; Han et al. 2017; Uehara et al. 2017). Furthermore, RBM39 function has been linked to malignant progression, and its expression is upregulated in several cancers, including small cell lung carcinoma, breast cancer, and colorectal adenoma (Bangur et al. 2002; Mercier et al. 2009; Sillars-Hardebol et al. 2012; Chai et al. 2014). More recently, RBM39 was identified as one of the top candidates to be selectively required in AML from a comprehensive clustered regularly interspaced short palindromic repeats/CRISPR-associated protein 9 (CRISPR/ Cas9) domain-focused screen targeting RBDs of 490 RBPs. Increasing its significance in hematological malignancies, $R B M 39$ was also found to be up-regulated in AML patients compared to normal hematopoietic cells, based on transcriptome analysis of The Cancer Genome Atlas (TCGA) (Wang et al. 2019).

Because RBM39 was found to be required in AML, a CRISPR/Cas9 domain screen was used to further analyze RBM39 essential protein domains by targeting its three RRM domains and its SR region. sgRNAs targeting RRM1 and RRM2 were more selectively depleted, and targeting these two domains delayed leukemogen- 
esis in vivo. Thus, these data suggest that the requirement of RBM39 in AML relies on its RNA-binding activity of specific RBDs. Mechanistically, in AML RBM39 was demonstrated to interact with numerous proteins associated with the spliceosome, including SF3B1, and ribosome biogenesis, which is consistent with previous studies demonstrating the interactions of RBM39 with splicing factors. RBM39 was also determined to interact with 15 RBPs that exhibited strong essentiality in the CRISPR/Cas9 domain-focused screen. Moreover, loss of RBM39 resulted in RNA splicing changes, the most predominant being changes in cassette exon inclusion and exclusion. Interestingly, RBM39 depletion led to aberrant splicing of the homeobox A9 (HOXA9) targets BMI1 and MYB and, subsequently, to their down-regulation as a result of nonsense-medicated decay (NMD) (Wang et al. 2019).

In summary, these data suggest that RBM39 and its RBP network are required for AML survival, and by therapeutically targeting this RBM39 network, the changes of AML splicing can also be exploited.

\section{RBPs Regulating RNA Modifications \\ METTL3 \& $m^{6}$ A Modifications}

Posttranscriptional modifications of mRNAs have recently been elucidated as an additional layer in the regulation of gene expression, even though they were observed decades ago (Desrosiers et al. 1974; Rottman et al. 1974). In mRNA, $\mathrm{N}^{6}$-methyladenosine $\left(\mathrm{m}^{6} \mathrm{~A}\right)$ is the most abundant posttranscriptional modification and is involved in various aspects of mRNA metabolism, such as mRNA decay, export, and translation (Cantara et al. 2011; Meyer et al. 2012; Machnicka et al. 2013; Zheng et al. 2013; Linder et al. 2015). $\mathrm{m}^{6} \mathrm{~A}$ marks are dynamically added by "writers," removed by "erasers," and recognized by "readers."

The "writer" complex consists of methyltransferase-like 3 (METTL3) and methyltransferase-like 14 (METTL14) and is responsible for adding the methyl group to mRNAs. The "writer" complex is also made up of adaptor proteins that lead the METTL3-METTL14 complex to particular mRNAs. Wilms tumor 1-associated protein (WTAP) was the first adaptor protein identified. Other adaptor proteins include RNA-binding motif protein 15 (RBM15), its paralog RBM15B, and KIAA1429. ${ }^{6}$ A demethylases, known as "erasers," include fat mass and obesity associated (FTO) and AlkB homolog 5 (ALKBH5). The $\mathrm{m}^{6} \mathrm{~A}$ "readers" bind either directly or indirectly to the RNAs; these include the YT521-B homology (YTH) family proteins, hnRNP proteins, and eukaryotic initiation factor 3 (EIF3). They have been reviewed comprehensively, so this review will briefly describe the current findings regarding the role of FTO and METTL3 in AML (Dai et al. 2018; Vu et al. 2019).

First, a study determined that FTO is highly expressed in several subtypes of AML, and its depletion increased $\mathrm{m}^{6} \mathrm{~A}$ levels, induced apoptosis, and delayed leukemogenesis (Li et al. 2017). In contrast, certain mutant isocitrate dehydrogenase 1 or 2 (IDH1/2) AML cases demonstrate inhibition of FTO, leading to increased $\mathrm{m}^{6} \mathrm{~A}$ levels. Consistently, another study observed that IDH1/2 mutant cells had increased $\mathrm{m}^{6} \mathrm{~A}$ levels, likely because of inhibited FTO (Elkashef et al. 2017). Last, the metabolite R-2-hydroxyglutarate (R-2HG) was shown to have antileukemic activity, by directly inhibiting FTO activity and increasing $\mathrm{m}^{6} \mathrm{~A}$ levels in non-IDH-mutant lines (Su et al. 2018). Therefore, additional studies are necessary to further explore the context-dependent role of FTO in AML with attention to the mutational backgrounds.

Meanwhile, two studies found METTL3 to be essential in myeloid leukemia. METTL3 mRNA and protein were found to be highly expressed in human leukemia cell lines, which correlated with high $\mathrm{m}^{6}$ A levels. METTL3 depletion resulted in induced differentiation, increased apoptosis, cell cycle arrest, and delayed leukemogenesis in vivo (Barbieri et al. 2017; Vu et al. 2017a). One study showed that although METTL3 depletion increased $\mathrm{m}^{6} \mathrm{~A}$-marked transcripts, these transcripts had reduced translation. Some of these METTL3-regulated targets included MYC, BCL2, and phosphatase and tensin homolog (PTEN), which regulate cell survival and differentiation ( $\mathrm{Vu}$ et al. 2017a). 
The other study found METTL3 to bind chromatin, in particular to the transcriptional start site of active genes that have the CAATT-box binding protein CEBPZ binding motif. Interestingly, METTL3 induced $\mathrm{m}^{6} \mathrm{~A}$ marks on the mRNA transcript of these genes, enhancing their translation (Barbieri et al. 2017). More recently, two additional studies noted the key role METTL3 plays in hematopoietic stem cell (HSC) self-renewal, in which deletion of Mettl3 resulted in altered differentiation of HSCs. Both studies identified $M y c$ as a direct target of RNA methylation in HSCs with differential effects on either mRNA stability or translation in HSCs (Cheng et al. 2019; Lee et al. 2019).

METTL14, WTAP, and the $\mathrm{m}^{6} \mathrm{~A}$ reader YTHDF2 have also been implicated as oncogenes in leukemia. METTL14 depletion resulted in increased differentiation and reduced proliferation of AML, which is the same phenotype as seen with loss of METTL3. Mechanistically, this study found that METTL14 regulates mRNA targets $M Y B$ and $M Y C$ through $\mathrm{m}^{6} \mathrm{~A}$ and affects their mRNA stability and translation (Weng et al. 2018). Loss of WTAP also decreased proliferation and increased myeloid differentiation of AML cells (Bansal et al. 2014). YTHDF2 was found to be overexpressed in human AML and to be required for disease survival in murine and human AML. This study also determined that loss of YTHDF2 decreased the half-life of $\mathrm{m}^{6} \mathrm{~A}$ transcripts, including the tumor necrosis factor receptor Tnfrsf2 (Paris et al. 2019). Altogether, these studies strongly demonstrate critical roles for the "writer" complex and at least one $\mathrm{m}^{6} \mathrm{~A}$ reader in leukemia and support their potential as therapeutic targets. As METTL3 and METTL14 are the two components of the "writer" complex and their depletion in AML resulted in similar phenotypes, therapeutically targeting these two proteins will likely be redundant. However, targeting the $\mathrm{m}^{6} \mathrm{~A}$ "readers," such as YTHDF2, could be an alternative approach to target the $\mathrm{m}^{6} \mathrm{~A}$ network.

\section{RBM15}

The RNA-binding motif protein 15 (RBM15; also known as OTT1) belongs to the split end
(SPEN) family of proteins, which is characterized by three amino-terminal RRMs and a Spen paralog and ortholog carboxy-terminal domain (SPOC) (Wiellette et al. 1999). In Drosophila development, SPEN proteins control neuronal cell fate by regulating the expression of suppressor of hairless $(\mathrm{Su}(\mathrm{H})$; human homolog is RBPJ), a key transcriptional regulator involved in Notch signaling (Kuang et al. 2000). Similarly, RBM15 is required for normal embryonic development and HSC function (Raffel et al. 2007). Mechanistically, RBM15 has been observed to regulate both mRNA export and transcription (Hiriart et al. 2005; Uranishi et al. 2009; Zolotukhin et al. 2009).

$R B M 15$ was first identified in leukemia as one of the two genes involved in the $t(1 ; 22)$ translocation of acute megakaryoblastic leukemia (AMKL), a heterogeneous subtype of AML compromising about $10 \%$ of childhood AML. This chromosomal rearrangement results in an in-frame fusion of RBM15 to megakaryoblastic leukemia 1 (MKL1), with the fusion gene containing nearly the full-length coding regions of both genes. AMKL in non-Down syndrome infants has poor prognosis with a median survival of only eight months, and, importantly, this translocation is specific to this disease (Ma et al. 2001).

A knock-in mouse model of the RBM15MKL1 fusion resulted in abnormal fetal and adult hematopoiesis. Fetal liver RBM15-MKL1 Lineage ${ }^{\text {Low }} \mathrm{Scal}^{+} \mathrm{c}^{\mathrm{C}-\mathrm{Kit}^{+}}$stem and progenitor (LSK) cells demonstrated increased colonyforming efficiency because of increased multipotent myeloid progenitors, revealing aberrant differentiation of HSCs toward the megakaryotic lineage. RBM15-MKL1, in cooperation with an activating mutation of the thrombopoietin receptor myeloproliferative leukemia virus gene (MPL), MPL ${ }^{W 515 L}$, induced AMKL with low frequency in adult mice, with infiltration of the bone marrow, spleen, liver, and kidney with a mixture of immature megakaryocytic and erythroid elements. Additionally, RBM15-MKL1 expression deregulated the transcriptional activity of the Notch signaling pathway transcription factor RBPJ, which is consistent with previous literature describing a role for SPEN proteins in 
Notch signaling (Mercher et al. 2009). Moreover, RBM15 inhibited myeloid differentiation in the 32DWT18 myeloid precursor cell line through its interaction with RBPJ and, consequently, Notch signaling stimulation (Ma et al. 2007).

Another study revealed that RBM15-MKL1 associates with the histone methyltransferase SET domain containing 1B protein (SETD1B) through its SPOC domain. Forced expression of RBM15-MKL1 in murine megakaryotic leukemic cells resulted in enhanced proliferation in a SPOC domain-dependent manner, suggesting that the interaction between the RBM15-MKL1 fusion protein and SETD1B was required for transformation (Lee and Skalnik 2012). Moreover, RBM15 is a component of the RNA methylation "writer" complex. These data suggest an important role for RBM15 in leukemia and hematopoiesis; however, more research is necessary to delineate if these phenotypes are through a $\mathrm{m}^{6} \mathrm{~A}$-dependent pathway.

\section{RBPs Regulating Noncoding RNAs}

LIN28

The gene lin-28 was originally identified as a heterochronic gene required for normal development in Caenorhabditis elegans (Moss et al. 1997). The two mammalian RBP homologs, LIN28A and LIN28B, share 69\% amino acid sequence identity, and their role in developmental processes has been well-studied (Guo et al. 2006). Interestingly, LIN28A is one of the four factors, along with octamer-binding transcription factor 4 (OCT4), SRY-box 2 (SOX2), and NANOG, necessary to reprogram human somatic cells into induced pluripotent cells ( $\mathrm{Yu}$ et al. 2007). The LIN28 proteins function by blocking the biogenesis of let-7 micro-RNAs (miRNA)s, which are 18- to 24-nucleotide RNAs that regulate the stability and translation of their target RNAs. By binding to the terminal loop of pre-let-7 miRNAs, LIN28 proteins facilitate the recruitment of terminal uridylyl transferase 4 (TUT4), which leads to the addition of uracil residues. This uridylation inhibits Dicer processing of pre-let-7 and decreases levels of mature let-7 (Heo et al. 2009). The let-7 family of miRNAs act as tumor suppressors, as repression of let-7 enhances the expression of its targets, which include known oncogenes. For example, let-7 regulates targets such as cell cycle promoting genes, high mobility group AT-hook 2 (HMGA2), Kirsten rat sarcoma viral oncogene homolog (KRAS), and MYC, providing evidence for the role of LIN28 proteins in malignancies (Roush and Slack 2008; Chang et al. 2009).

LIN28A or LIN28B overexpression has been found in $\sim 15 \%$ of human malignancies with LIN28B expression being associated with poorly differentiated and aggressive tumors, such as colon and ovarian cancers (Viswanathan et al. 2009; King et al. 2011). Furthermore, LIN28B is overexpressed in peripheral T-cell lymphoma (PTCL) patient samples compared to activated $\mathrm{CD}^{+}$cells (Beachy et al. 2012). LIN28B expression was demonstrated to increase dramatically in $\mathrm{BC}-\mathrm{CML}$ and accelerated phase $\mathrm{CML}$ as compared with chronic phase (CP) CML. Interestingly, in these patient samples LIN28B expression also correlates with reduced let-7 transcripts and increased HMGA2 expression, suggesting that LIN28B drives CML progression through let-7 pathways (Viswanathan et al. 2009). Elevated LIN28B expression was also identified in about half of juvenile myelomonocytic leukemia patients, defining a novel fetal-like disease subgroup. Consistently, this subgroup also had reduced let-7 levels (Helsmoortel et al. 2016).

Mouse models overexpressing LIN28B developed lymphoma, as well as neuroblastoma, liver, and colorectal cancers (Beachy et al. 2012; Molenaar et al. 2012; Madison et al. 2013; Nguyen et al. 2014). Conversely, expression of LIN28A in a transgenic mouse resulted in developmental alterations, such as increased body and organ size (Zhu et al. 2010). Thus, these studies suggest that LIN28B might be sufficient to drive malignant transformation. Consistent with this hypothesis, overexpression of LIN28B in the hematopoietic compartment resulted in an aggressive and fatal PTCL in vivo with mice developing lymphadenopathy and 
splenomegaly. LIN28B expression led to reduced let-7 expression, increased interleukin 6 (IL6) and $c-M y c$ levels, and nuclear factor $-\kappa \mathrm{B}$ $(\mathrm{NF}-\kappa \mathrm{B})$ activation. NF- $\mathrm{B}$ activation in turn resulted in enhanced transcription of Lin $28 b$, leading to a positive-feedback loop exacerbating the disease (Iliopoulos et al. 2010; Beachy et al. 2012).

Several different studies have also noted a link between c-Myc and LIN28B. In a B-cell lymphoma model, MYC was demonstrated to directly up-regulate LIN28B expression by binding to the $\operatorname{Lin} 28 b$ promotor, leading to reduced let-7 expression and impaired cell proliferation (Chang et al. 2009). In mixed-lineage leukemia (MLL)-associated leukemia, MLL fusion proteins drive MYC expression, leading to increased LIN28B. LIN28B can repress miR-150 precursors processing, which is also suppressed in AML (Jiang et al. 2012). Furthermore, LIN28B was found to be differentially expressed in MLL fusion protein transformed cell lines, correlating with $c-M y c$ expression. LIN28B negatively regulated miR-150 and to a weaker extent let- $7 g$, consistent with previous studies. Because let-7 repressed c-Myc, let-7g down-regulation due to increased LIN28B expression maintained $c$-Myc levels (Chen et al. 2016).

As further evidence of the LIN28B role in leukemia, depletion of LIN28B in AML resulted in decreased cell proliferation and colony formation and cell cycle arrest. Conversely, overexpression of LIN28B promoted cell proliferation and increased tumorigenicity. Depletion of LIN28B resulted in a decrease of insulin-like growth factor 2 mRNA-binding protein 1 (IGF2BP1), which was found to be regulated in a let-7-dependent mechanism and will be discussed later in the text (Zhou et al. 2017a). In another study, LIN28B was identified to be up-regulated by protein tyrosine phosphatase of regenerating liver 3 (PRL-3), which is up-regulated in AML patients (Zhou et al. 2017b).

Altogether these data suggest a requirement for LIN28B in lymphoma and leukemia through the regulation of let-7 and c-Myc pathways. Interestingly, a recent study suggests that LIN28A may act as a tumor suppressor, as overexpression of LIN28A in the OCI-AML3 cell line resulted in cell cycle arrest and myeloid differentiation (De Luca et al. 2017). Thus, further studies investigating the dichotomy of these two LIN28 proteins could prove useful for a deeper understanding of how they function in hematological malignancies.

\section{RBPs Regulating mRNA Stability and Translation}

\section{HuR}

Human antigen $\mathrm{R}(\mathrm{HuR})$ is a member of the human embryonic abnormal vision family of proteins, and although other members of this family are expressed exclusively in neuronal tissues, HuR is ubiquitously expressed (Akamatsu et al. 1999; Lu and Schneider 2004). Upon stimulation, HuR translocates to the cytoplasm, where it regulates the mRNA stability and translation of a number of transcripts by binding to U- or AU-rich elements (AREs) within 3' UTRs (Brennan and Steitz 2001; Wurth and Gebauer 2015). HuR can also bind to introns or the 5' UTR of some mRNAs, suggesting that HuR may have a role in precursor mRNA (premRNA) processing (Mukherjee et al. 2011). It has been suggested that HuR stabilizes mRNAs by interfering with the binding of ARE-binding proteins or miRNAs, but the extent of interplay between $\mathrm{HuR}$ and miRNAs remains unclear (Lebedeva et al. 2011).

$\mathrm{HuR}$ is essential for postnatal hematopoiesis as global deletion induced atrophy of the spleen, thymus, and lymph nodes with reduction of lymphoid, myeloid, and erythroid progenitors in the bone marrow (Ghosh et al. 2009). In regard to malignant hematopoiesis, HuR is overexpressed in the M4 subtype of AML, which correlates with high expression levels of eukaryotic initiation factor 4E (eIF4E), an essential translation factor that will be discussed later in the text (Topisirovic et al. 2009b). Furthermore, $\mathrm{HuR}$ and eIF4E collaborate to sustain tumorigenesis as HuR promotes eIF4E expression by increasing the stability of its transcripts. In turn, eIF4E stimulates the translation of pro-oncogenic targets that are also stabilized by HuR (Topisirovic et al. 2009a). These data suggest an 
important role for HuR in normal and malignant hematopoiesis, but further studies elucidating how HuR regulates mRNA stability or processing are needed.

\section{elF4F Protein Complex}

The well-characterized eukaryotic initiation factor $4 \mathrm{~F}$ (eIF4F) is a heterotrimeric protein complex consisting of three subunits: the capbinding protein eIF4E, the DEAD-box RNA helicase eIF4A, and the scaffold protein eIF4G. The eIF4F complex promotes eukaryotic translation initiation by mediating the mRNA $5^{\prime}$ cap function. The mRNA $5^{\prime}$ cap structure is an important aspect of cap-dependent translation regulation as it has important roles in RNA metabolism, including splicing, $3^{\prime}$ end processing, nucleocytoplasmic transport stability, and translation. Functionally, eIF4F binds to mRNA through the interaction of eIF4E to the mRNA $5^{\prime} 7$-methyl guanosine $\left(\mathrm{m}^{7} \mathrm{G}\right)$ cap and eIF4G to the mRNA. eIF4A then unwinds the mRNA 5' UTR secondary structure to create a binding site for the eukaryotic small ribosomal subunit (40S) (Parsyan et al. 2011). To note, mRNAs with extensive $5^{\prime}$ secondary structure have poor translation, so binding of eIF4E to the cap as well as the role of eIF4A are critical for their translation (Sonenberg and Gingras 1998). As eIF4E is the component that directly binds to the $5^{\prime}$ cap, most studies have focused on this key participant and its regulation.

Regulation of eIF4E is mostly accomplished by phosphorylation, as phosphorylated eIF4E has higher binding affinity to the $5^{\prime}$ cap and increases translation rates (Minich et al. 1994). Additionally, eIF4E-binding protein 1 (4EBP1) prevents the assembly of eIF4F by competing with eIF4G for the binding to eIF4E. Phosphorylation of $4 \mathrm{EBP} 1$ causes its dissociation with eIF4E, thus stimulating cap-dependent translation (Haghighat et al. 1995). Moreover, the phosphoinositide 3-OH kinase (PI3K) pathway is the major regulator of 4EBP1 phosphorylation. Activation of the downstream protein kinase B (AKT) by phosphorylation activates mammalian target of rapamycin complex 1 (mTOR), which in turn phosphorylates ribo- somal protein S6 kinase (p70S6K) and 4EBP1 (Gingras et al. 1998; Wendel et al. 2004). Interestingly, oncogenic transformation by $\mathrm{AKT}$ is dependent on its phosphorylation of p70S6K and $4 \mathrm{EBP} 1$, and thus regulation of translation initiation through eIF4E (Aoki et al. 2001).

The dysregulation of eIF4E has been described in several malignancies. eIF4E was observed to accelerate lymphomagenesis in a manner similar to AKT, displaying a high proliferation-to-apoptosis ratio and a resistance to chemotherapy. Unlike AKT-driven lymphomas, these eIF4E-lymphomas were derived from a more mature B-cell type and were resistant to the combination of chemotherapy and mTOR inhibitor rapamycin in vivo, possibly because eIF4E acts downstream of mTOR (Wendel et al. 2004). eIF4E is also overexpressed in $\mathrm{FAB}$ M4/M5 primary AML and BC-CML patient samples but not in M1/M2 AML, acute lymphoblastic leukemia (ALL), or CP-CML patient samples. Furthermore, elevated eIF4E blocked monocytic and granulocytic differentiation, contributing to leukemogenesis. Interestingly in these AML and CP-CML, eIF4E contributed to leukemogenesis through its role in mRNA transport (Topisirovic et al. 2003). Similarly, a number of previous studies have described a role for nuclear eIF4E in promoting the cytoplasmic transport of specific mRNAs through its $5^{\prime}$ cap-binding activity (Lejbkowicz et al. 1992; Strudwick and Borden 2002).

Similar to eIF4E, eIF4A was determined to accelerate T-cell acute lymphoblastic leukemia (T-ALL) development in vivo. Transcriptomescale ribosome footprinting revealed that eIF4A-dependent transcripts contain the 12nucleotide guanine quartet $(\mathrm{CGG})_{4}$ motif or a similar but shorter 9-nucleotide motif, which form RNA G-quadruplex structures. Thus, eIF4A is necessary for the translation of mRNAs containing G-quadruplexes in their $5^{\prime}$ UTRs, such as MYC, MYB, NOTCH, cyclin-dependent kinase 6 (CDK6), and BCL2 transcripts (Wolfe et al. 2014).

Altogether, these data propose that the translation initiation factor eIF4F, consisting of eIF4E, eIF4A, and eIF4G, plays an important role in maintaining the translation of a wide 
variety of crucial leukemia and lymphoma oncogenes and transcription factors.

\section{IGF2BPs and IGFBPs}

The insulin-like growth factor 2 mRNA-binding protein family (IGF2BPs) consists of three structurally and functionally related paralogs: IG2BP1, IGF2BP2, and IGF2BP3. These three proteins contain two amino-terminal RRMs and four carboxy-terminal $\mathrm{KH}$ domains. Additionally, these proteins are highly similar at the protein level, sharing $>56 \%$ amino acid sequence identity. IGF2BP1 and IGF2BP3 share an even higher similarity of $73 \%$ homology, suggesting that the proteins play similar biochemical functions. These cytoplasmic RBPs bind to their target mRNAs to form ribonucleoprotein complexes (mRNPs), affecting the localization, stability, and translation of their target mRNAs (Bell et al. 2013). In vitro studies have demonstrated that IGF2BPs bind to their target mRNAs through their $\mathrm{KH}$ domains, whereas their RRMs could be involved in the stabilization of mRNPs with surprisingly long half-lives (Farina et al. 2003; Nielsen et al. 2004). These stable mRNPs allow for "long-distance" transport and transient storage of their target mRNAs. Studies have observed that signaling events, such as phosphorylation of IGF2BPs, are likely to be involved in the controlled release of their target mRNAs leading to mRNA decay or protein synthesis (Hüttelmaier et al. 2005; Git et al. 2009; Dai et al. 2011). IGF2BPs are involved in important aspects of cell function, such as metabolism, proliferation, and differentiation. IGF2BP1 and IGF2BP3 are oncofetal proteins, being highly expressed during embryogenesis and in many cancers. Although many studies highlight their significance and prognostic ability in epithelial and soft tissue tumors, their role in malignant hematopoiesis remains to be completely understood (Stoskus et al. 2011; Bell et al. 2013; Lederer et al. 2014).

IGF2BP expression has been extensively studied in lymphomas; immunohistochemical analyses demonstrated high expression in positive classical or lymphocyte-predominant Hodgkin lymphomas. One study noted that
IGF2BP1 is highly expressed in Hodgkin's lymphoma, as well as various B-cell lymphomas (Natkunam et al. 2007). However, IGF2BP3 seems to be the predominant paralog expressed in primary lymphomas, based on reverse transcription-polymerase chain reaction (RT-PCR) analyses of a small lymphoma cohort. Furthermore, IGF2BP3 expression was also observed in a small percentage of AML samples (Natkunam et al. 2007; King et al. 2009; Navarro et al. 2012; Tang et al. 2013; Lederer et al. 2014). Another study determined that IGF2BP1 is overexpressed in ETV6/RUNX1-postive leukemia, whereas IGF2BP3 is overexpressed in MLL/ AF4-positive leukemia. Additionally, IGF2BP3 has also been shown to be a marker of disease aggressiveness in BCR/ABL1-postive ALL (Stoskus et al. 2011). IGF2BP3 is one of the most dysregulated genes in MLL-translocated B-cell acute lymphoblastic leukemia (B-ALL) and is essential for B-ALL cell survival. Because of the difficulty in raising paralog-specific antibodies, these immunohistochemical analyses of IGF3BP1 and IGF2BP3 expression should be carefully evaluated and further studies are needed to confirm their expression patterns in hematological malignancies (Bell et al. 2013).

Depletion of IGF2BP3 in a human CML cell line resulted in reduced cell growth, enhanced $\gamma$ irradiation-induced apoptosis, and reduced IGF2 expression. Mechanistically, IGF2BP3 was demonstrated to bind to the $5^{\prime}$ UTR of IGF2 and promote its translation (Liao et al. 2005, 2011). IGF2BP3 has also been found to bind to the $3^{\prime}$ UTRs of other target transcripts, which include oncogenes $c-M y c$ and $C D K 6$, and to maintain the translation of these targets. IGF2BP3 overexpression led to enhanced expression of MYC and CDK6 in B-ALL cells as well as hematopoietic progenitor cells in vivo (Palanichamy et al. 2016). However, there is a lack of studies on the mechanistic function of IGF2BP1 in lymphomas. Further studies are needed for a comprehensive identification of shared and unique targets bound and regulated by IGF2BP1 and IGF2BP3 in malignant hematopoiesis.

The insulin-like growth factor-binding protein family (IGFBPs) regulate insulin-like 
growth factor 1 and 2 (IGF1 and IGF2) availability as well as their binding to the IGF1 receptor (IGF1R). A recent study implicated IGFBP7 as a tumor suppressor in AML. Previous work established that IGFBP7 inhibits IGF1 and IGF2 from binding to IGF1R in breast cancer, thus suppressing IGF1R signaling and tumor cell growth (Evdokimova et al. 2012). Consistent with this finding, low IGFBP7 expression correlates with poor prognosis in patients with AML or hepatocellular carcinoma (Tomimaru et al. 2012; Verhagen et al. 2018). Additionally, overexpression of IGFBP7 induced apoptosis and $\mathrm{G}_{2}$ cell cycle arrest in AML cells (Verhagen et al. 2014). More recently, IGFBP7 was found to be differentially expressed in leukemia stem cells (LSCs) and HSCs, in which LSCs were characterized by low IGFBP7 expression. Moreover, overexpression of IGFBP7 in primary AML cells resulted in decreased cell survival and increased differentiation and chemotherapy sensitivity. Importantly, forced IGFBP7 expression did not affect HSC survival (Verhagen et al. 2018).

Overall, these data suggest a requirement for IGF2BP3 in lymphoma and leukemia through the $3^{\prime}$ UTR regulation of its target transcripts, MYC and CDK6. However, the role that IGF2BP3's related paralog IGF2BP1 plays in malignant hematopoiesis remains unclear. Additionally, IGFBP7 seems to act as a tumor suppressor in leukemia, yet its mechanism remains unstudied.

\section{MSI2}

The Musashi RNA-binding protein 2 (MSI2) belongs to the mammalian Musashi family RBPs. The two mammalian Msi genes, Msil and $M s i 2$, have essential roles as oncoproteins in various tumor types, but have been most extensively studied in colorectal cancers and hematopoietic malignancies. MSI1 and MSI2 share high homology and are characterized by two tandem RRMs and a carboxy-terminal polyA binding protein association domain. They both have similar binding specificities to target RNAs containing a minimum UAG sequence present in the $3^{\prime}$ UTR. Once bound, MSI interacts with the poly(A) binding proteins and competes for eIF4G, leading to the inhibition of translation (Kawahara et al. 2008). The Msi family has also been implicated in controlling polyadenylation of specific mRNAs in Xenopus oocytes and alternative splicing in photoreceptor cells and neurons, suggesting that their role is not solely limited to inhibition of translation (Charlesworth et al. 2006; Murphy et al. 2016).

In hematopoietic malignancies, the significance of MSI2 was first identified in several BCCML patients harboring the MSI2-HOXA9 translocation (Barbouti et al. 2003). Later, MSI2-EVI rearrangement was found in myeloid leukemia patients (De Weer et al. 2008) and a PAX5-MSI2 fusion was recently observed in BALL (Wang et al. 2017). Yet, it remains unclear if and how these MSI2 fusions contribute to disease development or progression.

Additionally, MSI2 expression is elevated in CLL, adult B-ALL, T-ALL, MDS, and AML. $M S I 2$ is up-regulated during disease progression in MDS and CML, and expression levels correlate with poor clinical prognosis in most of these hematological malignancies (adult B-ALL, MDS, CML, and AML) (Ito et al. 2010; Kharas et al. 2010; Pereira et al. 2012; Thol et al. 2013; Ho et al. 2016; Taggart et al. 2016).

Besides its expression in patients, functional studies using several leukemic mouse models have shown a requirement for MSI2 in leukemic progression and stem cell renewal. In a BC-CML model, deletion or depletion of MSI2 resulted in reduced leukemogenesis and forced MSI2 expression drove a more aggressive CML (Kharas et al. 2010). Similarly, MSI2 deletion led to a reversal of MDS phenotypes, and forced expression of MSI2 drove MPN and MDS/AML in a NUP98-HOXD13 mouse model (Taggart et al. 2016). Depletion of MSI2 in human AML and BC-CML cell lines resulted in reduced proliferation and increased apoptosis (Kharas et al. 2010; Kharas and Lengner 2017). MSI2 was also found to be required in maintaining AML LSCs in an MLL-AF9 AML murine model (Park et al. 2015).

Mechanistically, MSI has been linked to Notch signaling as MSI1 has been identified 
to repress the translation of NUMB, and MSI2 overexpression resulted in decreased NUMB in CML cells (Ito et al. 2010). In a murine leukemia model, MSI2 was determined to maintain the mixed-lineage leukemia self-renewal program by binding to the transcripts encoding IKAROS family zinc finger 2 (IKZF2), HOXA9, and MYC and promoting their translation (Park et al. 2015). Other studies reported Tetrespanin-3 (TSPAN3), FMS-like tyrosine kinase 3 (FLT3), and branched-chain amino acid aminotransferase 1 (BCAT1) as direct MSI2 targets in AML and BC-CML cells (Kwon et al. 2015; Hattori et al. 2017a, b).

Altogether, these studies determine a crucial functional role for MSI2 in leukemia. Although MSI2 direct targets have started to be studied, further genome-wide target analysis will advance our knowledge of MSI2 downstream targets and their functions.

\section{SYNCRIP}

Synaptotagmin-binding, cytoplasmic RNA-interacting protein (SYNCRIP), also known as heterogeneous nuclear ribonucleoprotein Q (hnRNPQ), has three tandem RRMs and has been implicated in regulating RNA processing and protein (Grosset et al. 2000; Mizutani et al. 2000; Cho et al. 2007; Stohr et al. 2008). Previous studies have also suggested that SYNCRIP plays a role in neuronal morphogenesis (Chen et al. 2012; Xing et al. 2012). Regarding malignant hematopoiesis, a pooled in vivo shRNA screening of the MSI2 interactome identified SYNCRIP as a MSI2 protein interactor and a novel regulator of leukemia. SYNCRIP was found to be required for the survival of murine leukemia cells in vitro and in vivo but dispensable for normal hematopoiesis. Similarly, depletion of SYNCRIP in human leukemia cells resulted in decreased cell proliferation, induction of apoptosis, and increased differentiation. Mechanistically, SYNCRIP was found to coregulate the LSC gene expression program with MSI2 by binding to MSI2 mRNA targets IKZF2, MYC, and HOXA9. Furthermore, SYNCRIP was determined to directly regulate the translation of HOXA9, while overexpression of HOXA9 par- tially rescued the SYNCRIP-depletion phenotype (Vu et al. 2017b).

Conversely, SYNCRIP was identified in another study as a tumor suppressor in T-ALL with chromosome $6 \mathrm{q}$ deletion. $6 \mathrm{q}$ deletion led to the silencing of both SYNCRIP and small nucleolar RNA host gene 5 (SNHG5), a noncoding snoRNA. This dual silencing accelerated leukemogenesis and decreased ribosome and mitochondrial activities (Gachet et al. 2018). Together, these recent studies highlight SYNCRIP as both an oncogene and a tumor suppressor, yet additional studies are needed to determine whether its role is disease-specific and elucidate its mechanism in each context.

\section{hnRNPK}

Heterogeneous nuclear ribonucleoprotein $\mathrm{K}$ (hnRNPK) is a nucleocytoplasmic shuttling protein, which regulates gene transcription and mRNA metabolism upon binding to DNA or RNA. One study noted that the $\mathrm{p} 210^{\mathrm{BCR} / \mathrm{ABL}}$ oncoprotein elevated hnRNPK expression by enhancing $h n R N P K$ transcription and mRNA stability. hnRNPK depletion and interference with its translation activity in these BCR/ABLtransformed cells decreased cell proliferation and impaired leukemogenesis in vivo, in part through the translational regulation of $M Y C$ (Notari et al. 2006).

A more recent study implicated hnRNPK as a haploinsufficient tumor suppressor in hematologic malignancies. AML patients harboring a $9 \mathrm{q}$ deletion were found to have reduced HNRNPK expression. Hnrnpk haploinsufficient mice had reduced survival and were prone to develop hematologic malignancies, with increased genomic instability. Sixty-two percent of mice displayed a myeloproliferative phenotype, whereas $31 \%$ of mice developed lymphomas. Mechanistically, this study suggested that hnRNPK reduction reduced p21 mRNA expression, down-regulated CCAAT-enhancerbinding protein $(\mathrm{C} / \mathrm{EBP})$ and mRNA levels, and activated signal transducer and activator of transcription 3 (STAT3) signaling, regulating proliferation and differentiation pathways. Importantly, chromatin immunoprecipitation 
(ChIP) assays demonstrated that hnRNPK directly interacted with $p 21$ and $C / E B P \alpha / C /$ $E B P \beta$, whereas RNA immunoprecipitation revealed an interaction between hnRNPK and $C / E B P \alpha$ mRNA. Thus, these data suggest that hnRNPK regulates cellular differentiation through the C/EBP pathways and proliferation through the p21/p53 and JAK/STAT pathways (Gallardo et al. 2015).

These studies implicate hnRNPK as both a tumor suppressor and an oncogene. Further studies will be needed to elucidate whether its role as a tumor suppressor is dependent on $9 q$ deletion in AML or if it is disease-specific, as well if its role is dependent on its RNA- or DNA-binding ability.

\section{THERAPEUTICS}

\section{Therapeutic Targeting of the Spliceosome}

During splicing, the spliceosome component $\mathrm{U} 2 \mathrm{snRNP}$ binds to the pre-mRNA via the interaction of its branchpoint-binding region and the branchpoint sequence in the intron. This binding is a crucial step in the formation of the catalytic center of the spliceosome. SF3B1, part of the U2snRNP complex, recognizes the premRNA intron branchpoint and cross-links to sequences both $5^{\prime}$ and $3^{\prime}$ of the branchpoint to facilitate this binding. Several bacterially derived products and their analogs target SF3B, resulting in blocking spliceosome assembly (Bonnal et al. 2012). These original products, including pladienolides and herboxidienes, were chemically unstable (Lee and Abdel-Wahab 2016). Further studies resulted in the development of the chemically stable analogs spliceostatin A (SSA), E7017, and sudemycins (Kaida et al. 2007; Kotake et al. 2007; Fan et al. 2011).

SSA binds to the SF3B complex, preventing its interaction with the pre-mRNA intron and destabilizing the spliceosome assembly (Corrionero et al. 2011). The inhibitor E7107 also targets the SF3B complex and prevents the conformational change of U2snRNP that exposes its branchpoint-binding region, thus blocking spliceosome formation as well (Folco et al. 2011). At first, it was unclear which component of the
SF3B complex these compounds targets. However, a recent functional genetic study on human colorectal cell lines that acquired resistance to pladienolide $\mathrm{B}$ determined that these compounds bind SF3B1. Even with this mechanistic understanding, additional research is needed to determine the transcriptome-wide effects of these compounds. Recent efforts have demonstrated that in vivo E7107 treatment resulted in changes to all classes of alternative splicing events, but further preclinical studies are necessary to fully predict the effects of these compounds (Lee et al. 2016).

\section{Therapeutic Targeting of RBM39}

Anticancer sulfonamides were recently determined to selectively degrade RBM39 through the recruitment of RBM39 to DCAF15, an adaptor protein for the CUL4/Ddb1 E3 ubiquitin ligase. This interaction led to the polyubiquitination and proteasomal degradation of RBM39. These sulfonamides include indisulam (also known as E7070), E7820, and chloroquinoxaline sulfonamide (Han et al. 2017; Uehara et al. 2017). Of note, DCAF15 was determined to be elevated in AML patient samples compared to hematopoietic progenitors. In vivo administration of indisulam in two AML cell line xenograft models extended survival and led to degradation of RBM39. Additionally, indisulam-treated patient-derived xenografts (PDXs) showed reduced leukemia burden. In contrast, both C57/B6 mice and immunocompromised mice transplanted with $\mathrm{CD}-\mathrm{CD} 34^{+}$cells showed no significant hematological effects, highlighting the differential effects of RBM39 loss on AML compared to normal hematopoietic cells (Wang et al. 2019).

Given the importance of change-in-function mutations in splicing factors SF3B1 and U2AF1 in AML and MDS and the interaction of RBM39 with both SF3B1 and U2AF1, it would follow that spliceosomal mutant AML cell lines were found to be the most sensitive cells to sulfonamides among many AML subtypes. Interestingly, AML cell lines with elevated expression of DCAF15 also had increased sensitivity to sulfonamides. RBM39 degradation was 
consistent among cell lines with or without the spliceosomal mutations, suggesting that the increased sensitivity of the spliceosomal mutant cells was due to their dependency on wild-type splicing function. Additionally, RBM39 degradation via E7820 treatment resulted in enhanced aberrant splicing and reduced expression of HOXA9 target genes BMI1 and $M Y B$, as well as GATA2, in spliceosomal mutant AML compared to its wild-type counterparts. Several RBPs were also found to be aberrantly spliced upon RBM39 degradation, supporting the idea of targeting the RBM39 RBP network (Wang et al. 2019).

Previously, sulfonamides had shown low rates of antitumor efficacy, which could be due to the fact that biomarkers of response were unknown (Owa et al. 1999; Supuran 2003). Together, these data suggest that the presence of spliceosomal mutations and elevated DCAF15 expression are good biomarkers to respond to sulfonamide treatment. Currently, indisulam combined with chemotherapy is in phase II clinical trials in patients with refractory or relapsed myeloid malignancies (Assi et al. 2018). Whereas indisulam is administered intravenously, E7820 is administered orally and has been tested as a highly effective second-generation sulfonamide in phase II clinical trials for solid tumors (Milojkovic Kerklaan et al. 2016). Thus, this study suggests further clinical investigation of E7820 in patients with myeloid malignancies with the proper biomarkers, and indeed, a multicenter clinical trial using E7820 is currently being planned (Wang et al. 2019).

\section{Therapeutic Targeting of LIN28}

Ongoing studies have been focusing on finding a small-molecule inhibitor of the LIN28/let-7 interaction. One study used a protein/RNA fluorescence resonance energy transfer (FRET) assay to identify a small-molecule inhibitor, which blocked the LIN28/let-7 interaction and rescued let-7 processing and function (Roos et al. 2016). Another study used fluorescence polarization to identify two small-molecule inhibitors for the LIN28 domains implicated in let-7 interactions. TPEN destabilizes the zinc-knuckle domain of
LIN28, while LI17 binds to the cold shock domain of LIN28 to block LIN28's suppression of let-7 in leukemia cells (Wang et al. 2018). Although more drug development is required, it is also important to understand how these small molecules relate to genetic perturbation.

\section{Therapeutic Targeting of Cap-Dependent Translation}

As mentioned previously, phosphorylation of 4EBP1 by mTOR allows for the release of eIF4E, and, consequently, the proper binding of eIF4E to eIF4G and the assembly if the translation initiation complex. Hence, eIF4E is an attractive target for therapeutic inhibition. The small-molecule inhibitor 4EGI-1 binds to eIF4E, preventing its interaction to eIF4G and inhibiting cap-dependent translation. Surprisingly, 4EGI-1 also enhances the binding of eIF4E to 4EBP1 (Moerke et al. 2007). Meanwhile, the antiviral drug ribavirin mimics the $\mathrm{m}^{7} \mathrm{G}$ cap structure, allowing it to bind and block eIF4E from its association to mRNA (Kentsis et al. 2004, 2005; Tan et al. 2008). In a phase II clinical trial of M4/M5 AML patients, ribavirin led to complete remission in one patient, partial remissions in two patients, and stable disease in four patients. Ribavirin caused the relocalization of eIF4E from the nucleus to the cytoplasm, and, interestingly, resistance to ribavirin occurred when eIF4E localized to the nucleus once again (Assouline et al. 2009).

Another therapeutic target in this pathway is mTOR, as its inhibition would prevent phosphorylation of 4EBP1 and p70S6K. Rapamycin and its analogs, RAD001 and CCI-779, block mTOR activity through an allosteric mechanism. Rapamycin binds to FK-binding protein 12 (FKBP12), and, subsequently, this complex inhibits the FKBP-rapamycin-binding (FRB) domain of mTOR. Rapamycin can restore normal HSC function and deplete LSCs; however, rapamycin is an incomplete $\mathrm{mTOR}$ inhibitor, as it only partially reduces 4EBP1 phosphorylation (Yilmaz et al. 2006). Although rapamycin strongly inhibits p70S6K activity, 4EBP1 recovers phosphorylation ability within hours of drug treatment (Choo et al. 2008; Kuo et al. 2011). A 
second-generation inhibitor, PP242, competes against ATP to bind mTOR's catalytic site and strongly blocks 4EBP1 phosphorylation. These findings demonstrated that PP242, unlike rapamycin, results in human leukemia cell death and delay of leukemic progression in vivo (Janes et al. 2010).

More recently, inhibition of another component of the translation initiation factor has been promising. Silvestrol inhibits eIF4A, thus blocking cap-dependent translation. Treatment with silvestrol led to cell death in primary human $\mathrm{T}$ ALL samples, cell lines, and murine T-ALLs in vitro. Similarly, silvestrol also delayed tumor growth in vivo. By targeting eIF4A, silvestrol drastically decreased the expression of eIF4A target transcripts, such as MYC, NOTCH, and BCL2 (Wolfe et al. 2014). Altogether, these findings support the potential to clinically develop small-molecule inhibitors of these RBPs.

\section{Therapeutic Targeting of MSI2}

A previous fluorescent polarization screen identified several small molecules with the ability to inhibit the RNA-binding activity of MSI (Minuesa et al. 2014). More recently, one of these small molecules, Ro 08-2750 (Ro), was characterized as an MSI RNA-competitive inhibitor. This study determined that Ro binds to MSI2 RRM1, reduces the proliferation of human AML cells, and decreases the binding of MSI2 to its mRNA targets as well as their protein expression (Minuesa et al. 2019). Overall, these data demonstrate the ability to therapeutically target MSI2 in leukemia.

\section{CONCLUSION AND FUTURE DIRECTIONS}

Posttranscriptional regulation is a tightly controlled process that allows cells to dictate the integrity, diversity, and supply of proteins. As highlighted herein, RBPs play a crucial role in all steps of this regulatory process and their dysregulation can result in hematopoietic malignancies (Fig. 2). Our increased knowledge in the identification of a greater number of these dysregulated RBPs, as well as their role in leukemia and lymphoma, has garnered excitement and increased interest in this emerging field. Furthermore, advances in sequencing technology and novel techniques to survey the riboproteome are expanding our understanding of the players involved in posttranscriptional regulation.

RBPs coordinate the fates of multiple mRNAs, but the principles underlying these interactions remain poorly understood. Questions remain regarding how RBPs achieve binding specificity and how they interact and compete with other RBPs. Moreover, the specific mRNA sequences bound by RBPs remain to be fully identified and their cell context specificity remains unknown. Cross-linking technologies coupled with sequencing (cross-linking immunoprecipitation [CLIP], photoactivatable ribonucleoside-enhanced cross-linking immunoprecipitation [PAR-CLIP], and high-throughput sequencing of RNA isolated by cross-linking immunoprecipitation [HITS-CLIP]) have been effective in discovering novel RBP targets but have limitations. A new technique, targets of RBPs identified by editing (TRIBE), has recently been developed and allows for the capture of RBP targets without the limitation of a large quantity of cells or specific RBP antibodies (McMahon et al. 2016; Hong 2017). Additionally, TRIBE allows for insight of RBP targets in rare subsets of cells, such as LSCs. Further studies are necessary to augment our knowledge of how these dynamic and multifunctional proteins modulate the gene expression program and disease.

Besides discovering how these RBPs regulate gene expression and malignancies, the identity of critical RBPs remain unknown. Several studies have recently suggested the importance of an RBP network in hematological malignancies. One study identified several RBPs that are essential for AML survival through a CRISPR/Cas9 $\mathrm{RBD}$ domain screen. Many of these have yet to be studied in the context of hematological malignancies, including DHX37, PABPN1, ZFP36L2, TRA2B, SRSF10, HNRNPH1, and SUPT6H. Comparing the CRISPR/Cas9 screen to identical screens in T-ALL, melanoma, and lung adenocarcinoma identified these RBPs as preferentially required in AML. Critically, the importance of 
RNA Regulators in Leukemia and Lymphoma

A

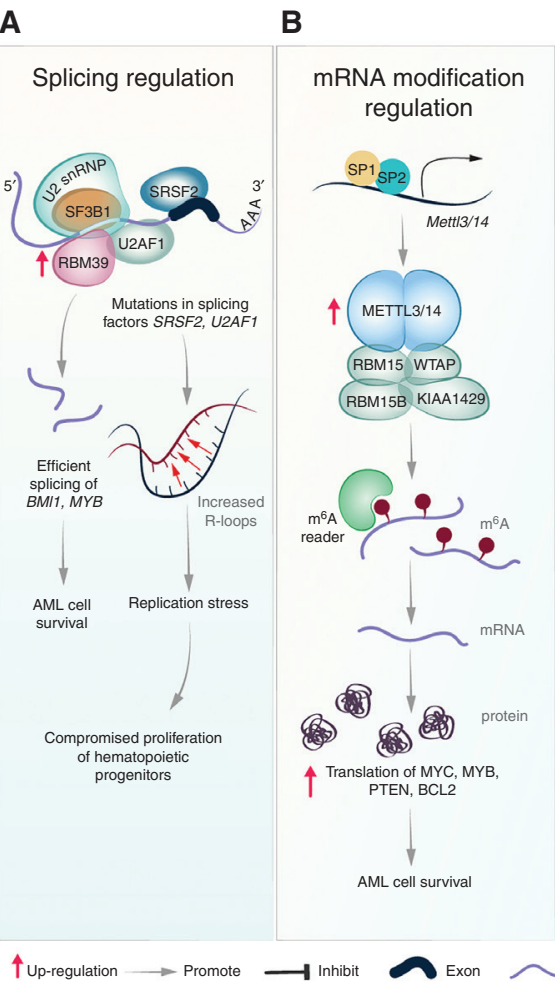

C
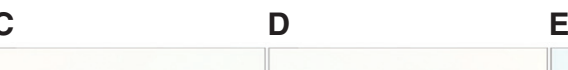

Noncoding RNA
regulation

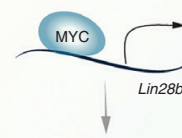

$\uparrow$ LIN28B TUT4

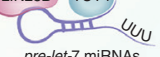

대라
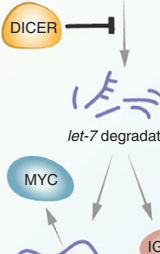

$\widetilde{\uparrow M C, I L G}$

levels

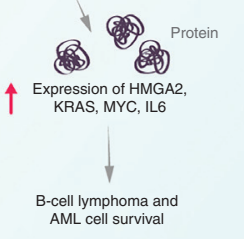

mRNA stability and Translational regulation translational regulation

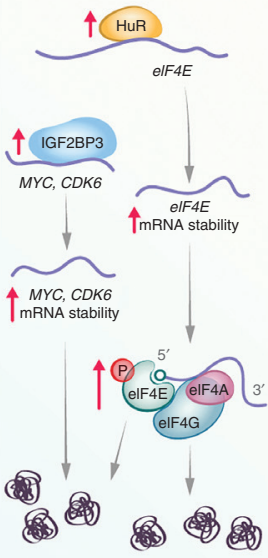

Translation of
MYC, CDK6 of

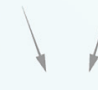
Lymphoma and
leukemia cell survival
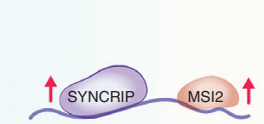

HOXA9
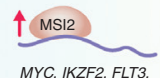
MYC, IKZF2, FLT3,
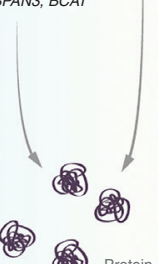

(3)

4 Translation of MYC, IKZF2, HOXA9, FLT
TSPAN3, BCAT

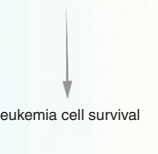

Figure 2. RNA-binding proteins (RBPs) are essential players in leukemia and lymphoma. Overview of the main RBPs and their regulatory pathways discussed in this review. (A) Mutations in splicing factors SRSF2 and U2AF1 contribute to the myelodysplastic syndrome (MDS) through elevated R loops and replication stress. In human acute myeloid leukemia (AML) cells, RNA-binding motif protein 39 (RBM39) interacts with the spliceosome, including splicing factor 3 subunit b1 (SF3B1), and elevated RBM39 expression maintains efficient splicing of homeobox A9 (HOXA9) targets BMI1 and MYB, resulting in enhanced cell survival. (B) In human leukemia cells, high expression of methyltransferase-like 3 (METTL3) and methyltransferase-like 14 (METTL14) increases global $\mathrm{N}^{6}$-methyladenosine ( $\mathrm{m}^{6} \mathrm{~A}$ levels). Increased $\mathrm{m}^{6} \mathrm{~A}$ on target genes $M Y C, M Y B, P T E N$, and $B C L 2$ promotes their translation, which results in enhanced cell survival. (C) In B-cell lymphoma, MYC binds to the Lin28b promoter, which drives elevated LIN28B expression. LIN28B binds to the terminal loop of pre-let-7 microRNAs (miRNAs) and recruits terminal uridylyl transferase 4 (TUT4), leading to the uridylation and degradation of prelet-7 miRNAs. Decreased levels of mature let-7 miRNAs result in increased levels of IL6 and MYC mRNA and elevated levels of high mobility group AT-hook 2 (HMGA2), Kirsten rat sarcoma viral oncogene homolog (KRAS), MYC, and IL6, resulting in enhanced cell survival. (D) In AML, overexpression of human antigen R (HuR) leads to increased stability of eIF4E transcripts and increased expression of eukaryotic initiation factor $4 \mathrm{E}$ (eIF4E). In lymphoma, elevated eIF4E expression results in efficient translation of MYC, cyclin-dependent kinase 6 (CDK6), MYB, BCL2, and NOTCH. Insulin-like growth factor 2 mRNA-binding protein 3 (IGF2BP3) is highly expressed in lymphomas and leukemias, and in B-ALL cells, IGF2BP3 binds to the $3^{\prime}$ UTR of target transcripts, including MYC and CDK6, increases their stability, and maintains their efficient translation. (E) Musashi RNAbinding protein 2 (MSI2) and synaptotagmin-binding, cytoplasmic RNA-interacting protein (SYNCRIP) are highly expressed in leukemia and they coregulate the LSC gene expression program through the regulation of HOXA9 translation. MSI2 also binds to the transcripts MYC, IKZF2, FLT3, TSPAN3, and BCAT and promotes their translation, which results in increased cell survival. 
an RBP network in AML was highlighted as RBM39 was found to interact with several of these essential RBPs and loss of RBM39 resulted in aberrant splicing of some of these same RBPs (Wang et al. 2019). Similarly, a pooled in vivo shRNA screen of the MSI2 interactome identified novel RBP regulators of leukemia, such as HNRNPA3, HNRNPR, and MYBBP1A, and suggested that a dysregulated RBP network is required for leukemia survival. Thus, further studies aimed to uncover the function of these RBPs are necessary (Vu et al. 2017b).

In summary, we emphasize the importance of understanding the regulation of the riboproteome to uncover novel targets and mechanisms that drive hematological malignancies. Future studies will be instrumental for uncovering the identity of essential RBPs, their RBP targets, and the relationship between these RBPs in hematological malignancies.

\section{ACKNOWLEDGMENTS}

We would like to acknowledge Sun Mi Park and Diu Nguyen from the Kharas laboratory for their critical reading of the manuscript and invaluable insights. We apologize in advance for any possible omissions due to space constraints or a failure to cite published work.

\section{REFERENCES}

Akamatsu W, Okano HJ, Osumi N, Inoue T, Nakamura S, Sakakibara SI, Miura M, Matsuo N, Darnell RB, Okano H. 1999. Mammalian ELAV-like neuronal RNA-binding proteins $\mathrm{HuB}$ and $\mathrm{HuC}$ promote neuronal development in both the central and the peripheral nervous systems. Proc Natl Acad Sci 96: 9885-9890. doi:10.1073/pnas.96 .17 .9885

Aoki M, Blazek E, Vogt PK. 2001. A role of the kinase mTOR in cellular transformation induced by the oncoproteins P3k and Akt. Proc Natl Acad Sci 98: 136-141. doi:10 $.1073 /$ pnas.98.1.136

Assi R, Kantarjian HM, Kadia TM, Pemmaraju N, Jabbour E, Jain N, Daver N, Estrov Z, Uehara T, Owa T, et al. 2018. Final results of a phase 2, open-label study of indisulam, idarubicin, and cytarabine in patients with relapsed or refractory acute myeloid leukemia and high-risk myelodysplastic syndrome. Cancer 124: 2758-2765. doi:10 $.1002 /$ cncr.31398

Assouline S, Culjkovic B, Cocolakis E, Rousseau C, Beslu N, Amri A, Caplan S, Leber B, Roy D, Miller WH Jr, et al. 2009. Molecular targeting of the oncogene eIF4E in acute myeloid leukemia (AML): A proof-of-principle clinical trial with ribavirin. Blood 114: 257-260. doi:10.1182/ blood-2009-02-205153

Bangur CS, Switzer A, Fan L, Marton MJ, Meyer MR, Wang T. 2002. Identification of genes over-expressed in small cell lung carcinoma using suppression subtractive hybridization and cDNA microarray expression analysis. Oncogene 21: 3814-3825. doi:10.1038/sj.onc.1205480

Bansal H, Yihua Q, Ganapathy S, Proia D, Penalva L, Uren P, Suresh U, Carew J, Karnad A, Weitman S, et al. 2014. WTAP is a novel oncogenic protein in acute myeloid leukemia. Leukemia 28: 1171-1174. doi:10.1038/leu .2014 .16

Barbieri I, Tzelepis K, Pandolifini L, Shi J, Millán-Zambrano G, Robson SC, Aspris D, Migliori V, Bannister AJ, Han N, et al. 2017. Promoter-bound METTL3 maintains myeloid leukaemia by $\mathrm{m}^{6} \mathrm{~A}$-dependent translation control. Nature 552: 126-131. doi:10.1038/nature24678

Barbouti A, Ho M, Johansson B, Lassen C, Nilsson P, Hagemeijer A, Mitelman F, Fioretos T. 2003. A novel gene, MSI2, encoding a putative RNA-binding protein is recurrently rearranged at disease progression of chronic myeloid leukemia and forms a fusion gene with HOXA9 as a result of the cryptic $t(7 ; 17)(\mathrm{p} 15 ; \mathrm{q} 23)$. Cancer Res 63: 1202-1206.

Beachy SH, Onozawa M, Chung YJ, Slape C, Bilke S, Francis P, Pineda M, Walker RL, Meltzer P, Aplan PD. 2012. Enforced expression of Lin28b leads to impaired T-cell development, release of inflammatory cytokines, and peripheral T-cell lymphoma. Blood 120: 1048-1059. doi:10 $.1182 /$ blood-2012-01-401760

Bell JL, Wächter K, Mühleck B, Pazaitis N, Köhn M, Lederer M, Hüttelmaier S. 2013. Insulin-like growth factor 2 mRNA-binding proteins (IGF2BPs): posttranscriptional drivers of cancer progression? Cell Mol Life Sci 70: 26572675. doi:10.1007/s00018-012-1186-Z

Bonnal S, Vigevani L, Valcárcel J. 2012. The spliceosome as a target of novel antitumour drugs. Nat Rev Drug Discov 11: 847-859. doi:10.1038/nrd3823

Brennan CM, Steitz JA. 2001. HuR and mRNA stability. Cell Mol Life Sci 58: 266-277. doi:10.1007/PL00000854

Cantara WA, Crain PF, Rozenski J, McCloskey JA, Harris KA, Zhang X, Vendeix FAP, Fabris D, Agris PF. 2011. The RNA modification database, RNAMDB: 2011 update. Nucleic Acids Res 39: D195-D201. doi:10.1093/nar/ gkq1028

Chai Y, Liu X, Dai L, Li Y, Liu M, Zhang JY. 2014. Overexpression of HCC1/CAPER $\alpha$ may play a role in lung cancer carcinogenesis. Tumor Biol 35: 6311-6317. doi:10.1007/s13277-014-1819-y

Chang TC, Zeitels LR, Hwang HW, Chivukula RR, Wentzel EA, Dews M, Jung J, Gao P, Dang CV, Beer MA, et al. 2009. Lin-28B transactivation is necessary for Myc-mediated let-7 repression and proliferation. Proc Natl Acad Sci 106: 3384-3389. doi:10.1073/pnas.0808300106

Charlesworth A, Wilczynska A, Thampi P, Cox LL, Macnicol AM. 2006. Musashi regulates the temporal order of mRNA translation during Xenopus oocyte maturation. EMBO J 25: 2792-2801. doi:10.1038/sj.emboj.7601159

Chen M, Manley JL. 2009. Mechanisms of alternative splicing regulation: Insights from molecular and genomics 
approaches. Nat Rev Mol Cell Biol 10: 741-754. doi:10 $.1038 / \mathrm{nrm} 2777$

Chen HH, Yu HI, Chiang WC, Lin YD, Shia BC, Tarn WY 2012. hnRNP Q regulates Cdc42-mediated neuronal morphogenesis. Mol Cell Biol 32: 2224-2238. doi:10 .1128/MCB.06550-11

Chen L, Sun Y, Wang J, Jiang H, Muntean AG. 2016. Differential regulation of the $\mathrm{c}-\mathrm{Myc} / \mathrm{Lin} 28$ axis discriminates subclasses of rearranged MLL leukemia. Oncotarget 7: 25208-25223.

Chen L, Chen JY, Huang YJ, Gu Y, Qiu J, Qian H, Shao C, Zhang X, Hu J, Li H, et al. 2018. The augmented R-loop is a unifying mechanism for myelodysplastic syndromes induced by high-risk splicing factor mutations. Mol Cell 69: 412-425.e6. doi:10.1016/j.molcel.2017.12.029

Cheng Y, Luo H, Izzo F, Pickering BF, Nguyen D, Myers R, Schurer A, Gourkanti S, Bruning JC, Vu LP, et al. 2019. $\mathrm{m}^{6} \mathrm{~A}$ RNA methylation maintains hematopoietic stem cell identity and symmetric commitment. Cell Rep 28: 1703-1716.e6. doi:10.1016/j.celrep.2019.07.032

Cho S, Park SM, Kim TD, Kim JH, Kim KT, Jang SK. 2007. $\mathrm{BiP}$ internal ribosomal entry site activity is controlled by heat-induced interaction of NSAP1. Mol Cell Biol 27: 368-383. doi:10.1128/MCB.00814-06

Choo AY, Yoon S, Kim SG, Roux PP, Blenis J. 2008. Rapamycin differentially inhibits S6Ks and 4E-BP1 to mediate cell-type-specific repression of mRNA translation. Proc Natl Acad Sci 105: 17414-17419. doi:10.1073/pnas .0809136105

Cooper TA, Wan L, Dreyfuss G. 2009. RNA and disease. Cell 136: 777-793. doi:10.1016/j.cell.2009.02.011

Corrionero A, Miñana B, Valcarcel J. 2011. Reduced fidelity of branch point recognition and alternative splicing induced by the antitumor drug spliceostatin A. Genes Dev 25: 445-459. doi:10.1101/gad.2014311

Dai N, Rapley J, Angel M, Yanik FM, Blower MD, Avruch J. 2011. mTOR phosphorylates IMP2 to promote IGF2 mRNA translation by internal ribosomal entry. Genes Dev 25: 1159-1172. doi:10.1101/gad.2042311

Dai D, Wang H, Zhu L, Jin H, Wang X. 2018. N6-methyladenosine links RNA metabolism to cancer progression. Cell Death Dis 9: 124. doi:10.1038/s41419-017-0129-x

Darnell RB. 2010. RNA regulation in neurologic disease and cancer. Cancer Res Treat 42: 125-129. doi:10.4143/crt .2010.42.3.125

De Luca L, Trino S, Laurenzana I, Tagliaferri D, Falco G, Grieco V, Bianchino G, Nozza F, Campia V, D’Alessio F, et al. 2017. Knockdown of miR-128a induces Lin28a expression and reverts myeloid differentiation blockage in acute myeloid leukemia. Cell Death Dis 8: e2849. doi:10 $.1038 /$ cddis.2017.253

Desrosiers R, Friderici K, Rottman F. 1974. Identification of methylated nucleosides in messenger RNA from Novikoff hepatoma cells. Proc Natl Acad Sci 71: 3971-3975. doi:10 .1073/pnas.71.10.3971

De Weer A, Speleman F, Cauwelier B, Van Roy N, Yigit N, Verhasselt B, De Moerloose B, Benoit Y, Noens L, Selleslag D, et al. 2008. EVI1 overexpression in $\mathrm{t}(3 ; 17)$ positive myeloid malignancies results from juxtaposition of EVI1 to the MSI2 locus at 17q22. Haematologica 93: 1903-1907. doi:10.3324/haematol.13192
Elkashef SM, Lin AP, Myers J, Sill H, Jiang D, Dahia PLM, Aguiar RCT. 2017. IDH mutation, competitive inhibition of FTO, and RNA methylation. Cancer Cell 31: 619-620. doi:10.1016/j.ccell.2017.04.001

Evdokimova V, Tognon CE, Benatar T, Yang W, Krutikov K, Pollak M, Sorensen PHB, Seth A. 2012. IGFBP7 binds to the IGF-1 receptor and blocks its activation by insulinlike growth factors. Sci Signal 5: ra92. doi:10.1126/scisig nal.2003184

Fan L, Lagisetti C, Edwards CC, Webb TR, Potter PM. 2011. Sudemycins, novel small molecule analogues of FR901464, induce alternative gene splicing. ACS Chem Biol 6: 582-589.

Farina KL, Hüttelmaier S, Musunuru K, Darnell R, Singer RH. 2003. Two ZBP1 KH domains facilitate $\beta$-actin mRNA localization, granule formation, and cytoskeletal attachment. J Cell Biol 160: 77-87. doi:10.1083/jcb .200206003

Fei DL, Motowski H, Chatrikhi R, Prasad S, Yu J, Gao S, Kielkopf CL, Bradley RK, Varmus H. 2016. Wild-type U2AF1 antagonizes the splicing program characteristic of U2AF1-mutant tumors and is required for cell survival. PLoS Genet 12: 1-26.

Folco EG, Coil KE, Reed R. 2011. The antitumor drug E7107 reveals an essential role for SF3b in remodeling U2 snRNP to expose the branch point-binding region. Genes Dev 25: 440-444. doi:10.1101/gad.2009411

Gachet S, El-Chaar T, Avran D, Genesca E, Catez F, Quentin S, Delord M, Thérizols G, Briot D, Meunier G, et al. 2018. Deletion 6q drives T-cell leukemia progression by ribosome modulation. Cancer Discov 8: 1614-1631. doi:10 .1158/2159-8290.CD-17-0831

Gallardo M, Lee HJ, Zhang X, Bueso-Ramos C, Pageon LR, McArthur M, Multani A, Nazha A, Manshouri T, ParkerThornburg J, et al. 2015. hnRNP K is a haploinsufficient tumor suppressor that regulates proliferation and differentiation programs in hematologic malignancies. Cancer Cell 28: 486-499. doi:10.1016/j.ccell.2015.09.001

Gerstberger S, Hafner M, Tuschl T. 2014. A census of human RNA-binding proteins. Nat Rev Genet 15: 829-845. doi: $10.1038 / \operatorname{nrg} 3813$

Ghosh M, Aguila HL, Michaud J, Ai Y, Wu MT, Hemmes A, Ristimaki A, Guo C, Furneaux H, Hla T. 2009. Essential role of the RNA-binding protein $\mathrm{HuR}$ in progenitor cell survival in mice. J Clin Invest 119: 3530-3543. doi:10 $.1172 /$ JCI38263

Gingras A, Kennedy SG, O'Leary MA, Sonenberg N, Hay N. 1998. 4E-BP1, a repressor of mRNA translation, is phosphorylated and inactivated by the Akt(PKB) signaling pathway. Genes Dev 12: 502-513. doi:10.1101/gad.12.4 .502

Git A, Allison R, Perdiguero E, Nebreda AR, Houliston E, Standart N. 2009. Vg1RBP phosphorylation by Erk2 MAP kinase correlates with the cortical release of Vg1 mRNA during meiotic maturation of Xenopus oocytes. RNA 15: 1121-1133. doi:10.1261/rna.1195709

Glisovic T, Bachorik JL, Yong J, Dreyfuss G. 2008. RNAbinding proteins and post-transcriptional gene regulation. FEBS Lett 582: 1977-1986. doi:10.1016/j.febslet .2008 .03 .004

Graubert TA, Shen D, Ding L, Okeyo-Owuor T, Lunn CL, Shao J, Krysiak K, Harris CC, Koboldt DC, Larson DE, et 
al. 2012. Recurrent mutations in the U2AF1 splicing factor in myelodysplastic syndromes. Nat Genet 44: 53-57. doi:10.1038/ng.1031

Graveley BR, Maniatis T. 1998. Arginine/serine-rich domains of SR proteins can function as activators of premRNA splicing. Mol Cell 1: 765-771. doi:10.1016/S10972765(00)80076-3

Grosset C, Chen CYA, Xu N, Sonenberg N, Jacquemin-Sablon H, Shyu AB. 2000. A mechanism for translationally coupled mRNA turnover: Interaction between the poly(A) tail and a $c$-fos RNA coding determinant via a protein complex. Cell 103: 29-40. doi:10.1016/S00928674(00)00102-1

Guo Y, Chen Y, Ito H, Watanabe A, Ge X, Kodama T, Aburatani H. 2006. Identification and characterization of lin-28 homolog B (LIN28B) in human hepatocellular carcinoma. Gene 384: 51-61. doi:10.1016/j.gene.2006.07.011

Haghighat A, Mader S, Pause A, Sonenberg N. 1995. Repression of cap-dependent translation by $4 \mathrm{E}$-binding protein 1: Competition with p220 for binding to eukaryotic initiation factor-4E. EMBO J 14: 5701-5709. doi:10.1002/j .1460-2075.1995.tb00257.x

Han T, Goralski M, Gaskill N, Capota E, Kim J, Ting TC, Xie Y, Williams NS, Nijhawan D. 2017. Anticancer sulfonamides target splicing by inducing RBM39 degradation via recruitment to DCAF15. Science 356: eaal3755.

Hattori A, McSkimming D, Kannan N, Ito T. 2017a. RNA binding protein MSI2 positively regulates FLT3 expression in myeloid leukemia. Leuk Res 54: 47-54. doi:10 $.1016 /$ j.leukres.2017.01.015

Hattori A, Tsunoda M, Konuma T, Kobayashi M, Nagy T, Glushka J, Tayyari F, McSkimming D, Kannan N, Tojo A et al. 2017b. Cancer progression by reprogrammed BCAA metabolism in myeloid leukaemia. Nature 545: 500-504. doi:10.1038/nature22314

Helsmoortel HH, Bresolin S, Lammens T, Cavé H, Noellke P, Caye A, Ghazavi F, de Vries A, Hasle H, Labarque V, et al. 2016. LIN28B overexpression defines a novel fetal-like subgroup of juvenile myelomonocytic leukemia. Blood 127: 1163-1172. doi:10.1182/blood-2015-09-667808

Heo I, Joo C, Kim YK, Ha M, Yoon MJ, Cho J, Yeom KH, Han J, Kim VN. 2009. TUT4 in concert with Lin28 suppresses microRNA biogenesis through pre-microRNA uridylation. Cell 138: 696-708. doi:10.1016/j.cell.2009 .08 .002

Hiriart E, Gruffat H, Buisson M, Mikaelian I, Keppler S, Meresse P, Mercher T, Bernard OA, Sergeant A, Manet E. 2005. Interaction of the Epstein-Barr virus mRNA export factor EB2 with human Spen proteins SHARP, OTT1, and a novel member of the family, OTT3, links Spen proteins with splicing regulation and mRNA export. J Biol Chem 280: 36935-36945. doi:10.1074/jbc .M501725200

Ho TC, Taggart J, Kharas MG. 2016. MUSASHI-2 duels in myelodysplastic syndromes. Cell Cycle 15: 1799-1800. doi:10.1080/15384101.2016.1176401

Hong S. 2017. RNA binding protein as an emerging therapeutic target for cancer prevention and treatment. J Cancer Prev 22: 203-210. doi:10.15430/JCP.2017.22.4.203

Hüttelmaier S, Zenklusen D, Lederer M, Dictenberg J, Lorenz M, Meng XH, Bassell GJ, Condeelis J, Singer RH. 2005. Spatial regulation of $\beta$-actin translation by Src-de- pendent phosphorylation of ZBP1. Nature 438: 512-515. doi:10.1038/nature04115

Iliopoulos D, Jaeger SA, Hirsch HA, Bulyk ML, Struhl K. 2010. STAT3 activation of miR-21 and miR-181b-1 via PTEN and CYLD are part of the epigenetic switch linking inflammation to cancer. Mol Cell 39: 493-506. doi:10 $.1016 /$ j.molcel.2010.07.023

Imai H, Chan EKL, Kiyosawa K, Fu XD, Tan EM. 1993. Novel nuclear autoantigen with splicing factor motifs identified with antibody from hepatocellular carcinoma. J Clin Invest 92: 2419-2426. doi:10.1172/JCI1 16848

Ito T, Kwon HY, Zimdahl B, Congdon KL, Blum J, Lento WE, Zhao C, Lagoo A, Gerrard G, Foroni L, et al. 2010. Regulation of myeloid leukaemia by the cell-fate determinant Musashi. Nature 466: 765-768. doi:10.1038/na ture 09171

Janes MR, Limon JJ, So L, Chen J, Lim RJ, Chavez MA, Vu C, Lilly MB, Mallya S, Ong ST, et al. 2010. Effective and selective targeting of $\mathrm{Ph}^{+}$leukemia cells using a TORC1/2 kinase inhibitor. Nat Med 16: 205-213. doi:10.1038/nm.2091

Jiang X, Huang H, Li Z, Li Y, Wang X, Gurbuxani S, Chen P, He C, You D, Zhang S, et al. 2012. Blockade of miR-150 maturation by $M L L$-fusion/MYC/LIN-28 is required for MLL-associated leukemia. Cancer Cell 22: 524-535. doi:10.1016/j.ccr.2012.08.028

Kaida D, Motoyoshi H, Tashiro E, Nojima T, Hagiwara M, Ishigami K, Watanabe H, Kitahara T, Yoshida T, Nakajima H, et al. 2007. Spliceostatin A targets SF3b and inhibits both splicing and nuclear retention of pre-mRNA. Nat Chem Biol 3: 576-583.

Kawahara H, Imai T, Imataka H, Tsujimoto M, Matsumoto K, Okano H. 2008. Neural RNA-binding protein Musashil inhibits translation initiation by competing with eIF4G for PABP. J Cell Biol 181: 639-653. doi:10.1083/ jcb.200708004

Kechavarzi B, Janga SC. 2014. Dissecting the expression landscape of RNA-binding proteins in human cancers. Genome Biol 15: R14. doi:10.1186/gb-2014-15-1-r14

Kentsis A, Topisirovic I, Culjkovic B, Shao L, Borden KLB. 2004. Ribavirin suppresses eIF4E-mediated oncogenic transformation by physical mimicry of the 7-methyl guanosine mRNA cap. Proc Natl Acad Sci 101: 18105-18110.

Kentsis A, Volpon L, Topisirovic I, Soll CE, Culjkovic B, Shao L, Borden KLB. 2005. Further evidence that ribavirin interacts with eIF4E. RNA 11: 1762-1766. doi:10.1261/ rna.2238705

Kharas MG, Lengner CJ. 2017. Stem cells, cancer, and MUSASHI in blood and guts. Trends Cancer 3: 347-356. doi:10.1016/j.trecan.2017.03.007

Kharas MG, Lengner CJ, Al-Shahrour F, Bullinger L, Ball B, Zaidi S, Morgan K, Tam W, Paktinat M, Okabe R, et al. 2010. Musashi-2 regulates normal hematopoiesis and promotes aggressive myeloid leukemia. Nat Med 16: 903-908. doi:10.1038/nm.2187

Kim E, Ilagan JO, Liang Y, Daubner GM, Lee SCW, Ramakrishnan A, Li Y, Chung YR, Micol JB, Murphy ME, et al. 2015. SRSF2 mutations contribute to myelodysplasia by mutant-specific effects on exon recognition. Cancer Cell 27: 617-630. doi:10.1016/j.ccell.2015.04.006

King RL, Pasha T, Roullet MR, Zhang PJ, Bagg A. 2009. IMP3 is differentially expressed in normal and neoplastic lym- 
phoid tissue. Hum Pathol 40: 1699-1705. doi:10.1016/j .humpath.2009.05.003

King C, Cuatrecasas M, Castells A, Sepulveda A, Lee JS, Rustgi AK. 2011. Lin28b promotes colon cancer progression and metastasis. Cancer Res 71: 4260-4268. doi:10 .1158/0008-5472.CAN-10-4637

Kon A, Yamazaki S, Nannya Y, Kataoka K, Ota Y, Nakagawa MM, Yoshida K, Shiozawa Y, Morita M, Yoshizato T, et al. 2018. Physiological Srsf2 P95H expression causes impaired hematopoietic stem cell functions and aberrant RNA splicing in mice. Blood 131: 621-635. doi:10.1182/ blood-2017-01-762393

Kotake Y, Sagane K, Owa T, Mimori-kiyosue Y, Shimizu H, Uesugi M, Ishihama Y, Iwata M, Mizui Y. 2007. Splicing factor SF3b as a target of the antitumor natural product pladienolide. Nat Chem Biol 3: 570-575.

Kuang B, Wu SC, Shin Y, Luo L, Kolodziej P. 2000. split ends encodes large nuclear proteins that regulate neuronal cell fate and axon extension in the Drosophila embryo. Development 1529: 1517-1529.

Kuo SH, Hsu CH, Chen LT, Lu YS, Lin CH, Yeh PY, Jeng HJ Gao M, Yeh KH, Cheng AL. 2011. Lack of compensatory pAKT activation and eIF4E phosphorylation of lymphoma cells towards mTOR inhibitor, RAD001. Eur J Cancer 47: 1244-1257. doi:10.1016/j.ejca.2011.01.003

Kwon HY, Bajaj J, Ito T, Blevins A, Konuma T, Weeks J, Lytle NK, Koechlein CS, Rizzieri D, Chuah C, et al. 2015. Tetraspanin 3 is required for the development and propagation of acute myelogenous leukemia. Cell Stem Cell 17: 152-164. doi:10.1016/j.stem.2015.06.006

Lebedeva S, Jens M, Theil K, Schwanhäusser B, Selbach M Landthaler M, Rajewsky N. 2011. Transcriptome-wide analysis of regulatory interactions of the RNA-binding protein HuR. Mol Cell 43: 340-352. doi:10.1016/j .molcel.2011.06.008

Lederer M, Bley N, Schleifer C, Hüttelmaier S. 2014. The role of the oncofetal IGF2 mRNA-binding protein 3 (IGF2BP3) in cancer. Semin Cancer Biol 29: 3-12. doi:10.1016/j.semcancer.2014.07.006

Lee SCW, Abdel-Wahab O. 2016. Therapeutic targeting of splicing in cancer. Nat Med 22: 976-986. doi:10.1038/nm .4165

Lee JH, Skalnik DG. 2012. Rbm15-Mkl1 interacts with the Setd1b histone H3-Lys4 methyltransferase via a SPOC domain that is required for cytokine-independent proliferation. PLoS ONE 7: 27-29.

Lee SCW, Dvinge H, Kim E, Cho H, Micol JB, Chung YR, Durham BH, Yoshimi A, Kim YJ, Thomas M, et al. 2016. Modulation of splicing catalysis for therapeutic targeting of leukemia with mutations in genes encoding spliceosomal proteins. Nat Med 22: 672-678. doi:10.1038/nm.4097

Lee SCW, North K, Kim E, Jang E, Obeng E, Lu SX, Liu B, Inoue D, Yoshimi A, Ki M, et al. 2018. Synthetic lethal and convergent biological effects of cancer-associated spliceosomal gene mutations. Cancer Cell 34: 225-241.e8. doi:10 .1016/j.ccell.2018.07.003

Lee H, Bao S, Qian Y, Geula S, Leslie J, Zhang C, Hanna JH, Ding L. 2019. Stage-specific requirement for Mettl3dependent $\mathrm{m}^{6} \mathrm{~A}$ mRNA methylation during haematopoietic stem cell differentiation. Nat Cell Biol 21: 700-709. doi:10.1038/s41556-019-0318-1
Lejbkowicz F, Goyer C, Darveaut A, Neron S, Lemieux R, Sonenberg N. 1992. A fraction of the mRNA $5^{\prime}$ capbinding protein, eukaryotic initiation factor $4 \mathrm{E}$, localizes to the nucleus. Proc Natl Acad Sci 89: 9612-9616. doi:10 $.1073 /$ pnas.89.20.9612

Li Z, Weng H, Su R, Weng X, Zuo Z, Li C, Huang H, Nachtergaele S, Dong L, Hu C, et al. 2017. FTO plays an oncogenic role in acute myeloid leukemia as a $\mathrm{N}^{6}$-methyladenosine RNA demethylase. Cancer Cell 31: 127141. doi:10.1016/j.ccell.2016.11.017

Liao B, Hu Y, Herrick DJ, Brewer G. 2005. The RNA-binding protein IMP-3 is a translational activator of insulin-like growth factor II leader-3 mRNA during proliferation of human K562 leukemia cells. J Biol Chem 280: 1851718524. doi:10.1074/jbc.M500270200

Liao B, Hu Y, Brewer G. 2011. RNA-binding protein insulinlike growth factor mRNA-binding protein 3 (IMP-3) promotes cell survival via insulin-like growth factor II signaling after ionizing radiation. J Biol Chem 286: 3114531152. doi:10.1074/jbc.M111.263913

Linder B, Grozhik AV, Olarerin-George AO, Meydan C, Mason CE, Jaffrey SR. 2015. Single-nucleotide-resolution mapping of $\mathrm{m}^{6} \mathrm{~A}$ and $\mathrm{m}^{6} \mathrm{Am}$ throughout the transcriptome. Nat Methods 12: 767-772. doi:10.1038/nmeth.3453

Liu H-X, Chew SL, Cartegni L, Zhang MQ, Krainer AR. 2000. Exonic splicing enhancer motif recognized by human SC35 under splicing conditions. Mol Cell Biol 20: 1063-1071. doi:10.1128/MCB.20.3.1063-1071.2000

Loerch S, Maucuer A, Manceau V, Green MR, Kielkopf CL. 2014. Cancer-relevant splicing factor CAPER $\alpha$ engages the essential splicing factor SF3b155 in a specific ternary complex. J Biol Chem 289: 17325-17337. doi:10.1074/jbc .M114.558825

Lu JY, Schneider RJ. 2004. Tissue distribution of AU-rich mRNA-binding proteins involved in regulation of mRNA decay. J Biol Chem 279: 12974-12979. doi:10.1074/jbc .M310433200

Lukong KE, Chang KW, Khandjian EW, Richard S. 2008. RNA-binding proteins in human genetic disease. Trends Genet 24: 416-425. doi:10.1016/j.tig.2008.05.004

Lunde BM, Moore C, Varani G. 2007. RNA-binding proteins: Modular design for efficient function. Nat Rev Mol Cell Biol 8: 479-490. doi:10.1038/nrm2178

Ma Z, Morris SW, Valentine V, Herbrick JA, Cui X, Bouman D, Li Y, Mehta PK, Nizetic D, Kaneko Y, et al. 2001. Fusion of two novel genes, RBM15 and MKL1, in the $\mathrm{t}(1 ; 22)(\mathrm{p} 13 ; \mathrm{q} 13)$ of acute megakaryoblastic leukemia. Nat Genet 28: 220-221. doi:10.1038/90054

Ma X, Renda MJ, Wang L, Cheng E, Niu C, Morris SW, Chi AS, Krause DS. 2007. Rbm15 modulates Notch-induced transcriptional activation and affects myeloid differentiation. Mol Cell Biol 27: 3056-3064. doi:10.1128/MCB .01339-06

Machnicka MA, Milanowska K, Oglou OO, Purta E, Kurkowska M, Olchowik A, Januszewski W, Kalinowski S, Dunin-Horkawicz S, Rother KM, et al. 2013. MODOMICS: A database of RNA modification pathways2013 update. Nucleic Acids Res 41: D262-D267. doi:10 $.1093 / \mathrm{nar} / \mathrm{gks} 1007$

Madison B, Liu Q, Zhong X, Hahn CM, Lin N, Emmet M, Stanger BZ, Rustgi AK. 2013. LIN28B promotes growth 
and tumorigenesis of the intestinal epithelium primarily via Let-7. Cancer Res 73: 2233-2245.

Makishima H, Visconte V, Sakaguchi H, Jankowska AM, Kar SA, Jerez A, Przychodzen B, Bupathi M, Guinta K, Afable MG, et al. 2012. Mutations in the spliceosome machinery, a novel and ubiquitous pathway in leukemogenesis. Blood 119: 3203-3210. doi:10.1182/blood-201112-399774

Malcovati L, Papaemmanuil E, Bowen DT, Boultwood J, Della Porta MG, Pascutto C, Travaglino E, Groves MJ, Godfrey AL, Ambaglio I, et al. 2011. Clinical significance of SF3B1 mutations in myelodysplastic syndromes and myelodysplastic/myeloproliferative neoplasms. Blood 118: 6239-6246. doi:10.1182/blood-2011-09-377275

Malcovati L, Karimi M, Papaemmanuil E, Ambaglio I, Jädersten M, Jansson M, Elena C, Galli A, Walldin G, Della Porta MG, et al. 2015. SF3B1 mutation identifies a distinct subset of myelodysplastic syndrome with ring sideroblasts. Blood 126: 233-241. doi:10.1182/blood-2015-03633537

McMahon AC, Rahman R, Jin H, Shen JL, Fieldsend A, Luo W, Rosbash M. 2016. TRIBE: Hijacking an RNA-editing enzyme to identify cell-specific targets of RNA-binding proteins. Cell 165: 742-753. doi:10.1016/j.cell.2016.03 .007

Meggendorfer M, Roller A, Haferlach T, Eder C, Dicker F, Grossmann V, Kohlmann A, Alpermann T, Yoshida K, Ogawa S, et al. 2012. SRSF2 mutations in 275 cases with chronic myelomonocytic leukemia (CMML). Blood 120: 3080-3088. doi:10.1182/blood-2012-01-404863

Mercher T, Raffel GD, Moore SA, Cornejo MG, Baudrybluteau D, Cagnard N, Jesneck JL, Pikman Y, Cullen D, Williams IR, et al. 2009. The OTT-MAL fusion oncogene activates RBPJ-mediated transcription and induces acute megakaryoblastic leukemia in a knockin mouse model. $J$ Clin Invest 119: 852-864.

Mercier I, Casimiro MC, Zhou J, Wang C, Plymire C, Bryant KG, Daumer KM, Sotgia F, Bonuccelli G, Witkiewicz AK, et al. 2009. Genetic ablation of caveolin-1 drives estrogenhypersensitivity and the development of DCIS-like mammary lesions. Am J Pathol 174: 1172-1190. doi:10.2353/ ajpath.2009.080882

Meyer KD, Saletore Y, Zumbo P, Elemento O, Mason CE, Jaffrey SR. 2012. Comprehensive analysis of mRNA methylation reveals enrichment in $3^{\prime}$ UTRs and near stop codons. Cell 149: 1635-1646. doi:10.1016/j.cell.2012.05.003

Milojkovic Kerklaan B, Slater S, Flynn M, Greystoke A, Witteveen PO, Megui-Roelvink M, de Vos F, Dean E, Reyderman L, Ottesen L, et al. 2016. A phase I, dose escalation, pharmacodynamic, pharmacokinetic, and food-effect study of $\alpha 2$ integrin inhibitor E7820 in patients with advanced solid tumors. Invest New Drugs 34: 329-337. doi:10.1007/s10637-016-0344-9

Minich WB, Balasta ML, Goss DJ, Rhoads RE. 1994. Chromatographic resolution of in vivo phosphorylated and nonphosphorylated eukaryotic translation initiation factor eIF-4E: increased cap affinity of the phosphorylated form. Proc Natl Acad Sci 91: 7668-7672. doi:10.1073/ pnas.91.16.7668

Minuesa G, Antczak C, Shum D, Radu C, Bhinder B, Li Y, Djaballah H, Kharas MG. 2014. A 1536-well fluorescence polarization assay to screen for modulators of the
MUSASHI family of RNA-binding proteins. Comb Chem High Throughput Screen 17: 596-609. doi:10.2174/ 1386207317666140609122714

Minuesa G, Albanese SK, Xie W, Kazansky Y, Worroll D, Chow A, Schurer A, Park S, Rotsides CZ, Taggart J, et al. 2019. Small-molecule targeting of MUSASHI RNA-binding activity in acute myeloid leukemia. Nat Commun 10: 1-15. doi:10.1038/s41467-019-10523-3

Mizutani A, Fukuda M, Ibata K, Shiraishi Y, Mikoshiba K. 2000. SYNCRIP, a cytoplasmic counterpart of heterogeneous nuclear ribonucleoprotein $\mathrm{R}$, interacts with ubiquitous synaptotagmin isoforms. J Biol Chem 275: 9823-9831. doi:10.1074/jbc.275.13.9823

Moerke NJ, Aktas H, Chen H, Cantel S, Reibarkh MY, Fahmy A, Gross JD, Degterev A, Yuan J, Chorev M, et al. 2007. Small-molecule inhibition of the interaction between the translation initiation factors eIF4E and eIF4G. Cell 128: 257-267.

Molenaar JJ, Domingo-Fernández R, Ebus ME, Lindner S, Koster J, Drabek K, Mestdagh P, Van Sluis P, Valentijn LJ, Van Nes J, et al. 2012. LIN28B induces neuroblastoma and enhances MYCN levels via let-7 suppression. Nat Genet 44: 1199-1206. doi:10.1038/ng.2436

Moss EG, Lee RC, Ambros V. 1997. The cold shock domain protein LIN-28 controls developmental timing in C. elegans and is regulated by the lin-4 RNA. Cell 88: 637-646. doi:10.1016/S0092-8674(00)81906-6

Mukherjee N, Corcoran DL, Nusbaum JD, Reid DW, Georgiev S, Hafner M, Ascano M, Tuschl T, Ohler U, Keene JD. 2011. Integrative regulatory mapping indicates that the RNA-binding protein HuR couples pre-mRNA processing and mRNA stability. Mol Cell 43: 327-339. doi:10 .1016/j.molcel.2011.06.007

Murphy D, Cieply B, Carstens R, Ramamurthy V, Stoilov P, Desplan C. 2016. The Musashi 1 controls the splicing of photoreceptor-specific exons in the vertebrate retina. PLoS Genet 12: e1006256. doi:10.1371/journal.pgen .1006256

Natkunam Y, Vainer G, Chen J, Zhao S, Marinelli RJ, Hammer AS, Hamilton-Dutoit S, Pikarsky E, Amir G, Levy R, et al. 2007. Expression of the RNA-binding protein VICKZ in normal hematopoietic tissues and neoplasms. Haematologica 92: 176-183. doi:10.3324/haematol.10724

Navarro A, Trapp V, Hartmann EM, Beà S, Campo E, Ott G, Rosenwald A. 2012. Increased tumor cell proliferation in mantle cell lymphoma is associated with elevated insulin-like growth factor 2 mRNA-binding protein $3 \mathrm{ex}-$ pression. Mod Pathol 25: 1227-1235. doi:10.1038/modpa thol.2012.84

Nguyen LH, Robinton DA, Seligson MT, Wu L, Li L, Rakheja D, Comerford SA, Ramezani S, Sun X, Parikh MS, et al. 2014. Lin $28 b$ is sufficient to drive liver cancer and necessary for its maintenance in murine models. Cancer Cell 26: 248-261. doi:10.1016/j.ccr.2014.06.018

Nielsen J, Kristensen MA, Willemoës M, Nielsen FC, Christiansen J. 2004. Sequential dimerization of human zipcode-binding protein IMP1 on RNA: A cooperative mechanism providing RNP stability. Nucleic Acids Res 32: 4368-4376. doi:10.1093/nar/gkh754

Notari M, Neviani P, Santhanam R, Blaser BW, Chang JS, Galietta A, Willis AE, Roy DC, Caligiuri MA, Marcucci G, et al. 2006. A MAPK/HNRPK pathway controls BCR/ 
ABL oncogenic potential by regulating MYC mRNA translation. Blood 107: 2507-2516. doi:10.1182/blood2005-09-3732

Obeng EA, Chappell RJ, Seiler M, Chen MC, Campagna DR, Schmidt PJ, Schneider RK, Lord AM, Wang L, Gambe RG, et al. 2016. Physiologic expression of Sf3b $1^{\mathrm{K} 700 \mathrm{E}}$ causes impaired erythropoiesis, aberrant splicing, and sensitivity to therapeutic spliceosome modulation. Cancer Cell 30: 404-417. doi:10.1016/j.ccell.2016.08.006

Owa T, Yoshino H, Okauchi T, Yoshimatsu K, Ozawa Y, Sug NH, Nagasu T, Koyanagi N, Kitoh K. 1999. Discovery of novel antitumor sulfonamides targeting G1 phase of the cell cycle. J Med Chem 42: 3789-3799. doi:10.1021/ jm9902638

Palanichamy JK, Tran TM, Howard JM, Contreras JR, Fernando TR, Sterne-Weiler T, Katzman S, Toloue M, Yan W, Basso G, et al. 2016. RNA-binding protein IGF2BP3 targeting of oncogenic transcripts promotes hematopoietic progenitor proliferation. J Clin Invest 126: 14951511. doi:10.1172/JCI80046

Papaemmanuil E, Cazzola M, Boultwood J, Malcovati L, Vyas P, Bowen D, Pellagatti A, Wainscoat JS, Hellstrom-Lindberg E, Gambacorti-Passerini C, et al. 2011. Somatic SF3B1 mutation in myelodysplasia with ring sideroblasts. N Engl J Med 365: 1384-1395. doi:10.1056/ NEJMoa1103283

Papaemmanuil, Gerstung M, Malcovati L, Tauro S, Gundem G, Van Loo P, Yoon CJ, Ellis P, Wedge DC, Pellagatti A, et al. 2013. Clinical and biological implications of driver mutations in myelodysplastic syndromes. Blood 122: 3616-3627. doi:10.1182/blood-2013-08-518886

Paris J, Morgan M, Campos J, Spencer GJ, Shmakova A, Ivanova I, Mapperley C, Lawson H, Wotherspoon DA, Sepulveda C, et al. 2019. Targeting the RNA $\mathrm{m}^{6} \mathrm{~A}$ reader YTHDF2 selectively compromises cancer stem cells in acute myeloid leukemia. Cell Stem Cell 25: 137-148.e6. doi:10.1016/j.stem.2019.03.021

Park S, Gönen M, Vu L, Minuesa G, Tivnan P, Barlowe TS, Taggart J, Lu Y, Deering RP, Hacohen N, et al. 2015. Musashi2 sustains the mixed-lineage leukemia-driven stem cell regulatory program. J Clin Invest 125: 1286 1298. doi:10.1172/JCI78440

Parsyan A, Svitkin Y, Shahbazian D, Gkogkas C, Lasko P, Merrick WC, Sonenberg N. 2011. mRNA helicases: The tacticians of translational control. Nat Rev Mol Cell Biol 12: $235-245$. doi: $10.1038 / n r m 3083$

Pereira JKN, Traina F, Machado-Neto JA, Duarte AdSS, Lopes MR, Saad ST, Favaro P. 2012. Distinct expression profiles of MSI2 and NUMB genes in myelodysplastic syndromes and acute myeloid leukemia patients. Leuk Res 36: 1300-1303. doi:10.1016/j.leukres.2012.06.010

Pereira B, Billaud M, Almeida R. 2017. RNA-binding proteins in cancer: Old players and new actors. Trends Cancer 3: 506-528. doi:10.1016/j.trecan.2017.05.003

Quesada V, Ramsay AJ, Lopez-Otin C. 2012. Chronic lymphocytic leukemia with SF3B1 mutation. $N$ Engl J Med 366: 2530. doi:10.1056/NEJMc1204033

Raffel GD, Mercher T, Shigematsu H, Williams IR, Cullen DE, Akashi K, Bernard OA, Gilliland DG. 2007. Ott1 (Rbm15) has pleiotropic roles in hematopoietic development. Proc Natl Acad Sci 104: 6001-6006. doi:10.1073/ pnas.0609041104
RNA Regulators in Leukemia and Lymphoma

Roos M, Pradère U, Ngondo RP, Behera A, Allegrini S, Civenni G, Zagalak JA, Marchand J-R, Menzi M, Towbin H, et al. 2016. A small-molecule inhibitor of Lin28. ACS Chem Biol 11: 2773-2781. doi:10.1021/acschembio $.6 \mathrm{~b} 00232$

Rottman F, Shatkin AJ, Perry RP. 1974. Sequences containing methylated nucleotides at the $5^{\prime}$ termini of messenger RNAs: Possible implications for processing. Cell 3: 197199. doi:10.1016/0092-8674(74)90131-7

Roush S, Slack FJ. 2008. The let-7 family of microRNAs. Trends Cell Biol 18: 505-516. doi:10.1016/j.tcb.2008.07 .007

Schaal TD, Maniatis T. 1999. Multiple distinct splicing enhancers in the protein-coding sequences of a constitutively spliced pre-mRNA. Mol Cell Biol 19: 261-273. doi:10 $.1128 / \mathrm{MCB} \cdot 19.1 .261$

Shirai CL, Ley JN, White BS, Kim S, Tibbitts J, Shao J, Ndonwi M, Wadugu B, Duncavage EJ, Okeyo-Owuor T, et al. 2015. Mutant U2AF1 expression alters hematopoiesis and pre-mRNA splicing in vivo. Cancer Cell 27: 631643. doi:10.1016/j.ccell.2015.04.008

Sillars-Hardebol AH, Carvalho B, Beliën JAM, De Wit M, Delis-Van Diemen PM, Tijssen M, Van De Wiel MA, Pontén F, Meijer GA, Fijneman RJA. 2012. CSE1L, DIDO1 and RBM39 in colorectal adenoma to carcinoma progression. Cell Oncol 35: 293-300. doi:10.1007/s13402012-0088-2

Sonenberg N, Gingras A. 1998. The mRNA 5' cap-binding protein eIF4E and control of cell growth. Curr Opin Cell Biol 10: 268-275. doi:10.1016/S0955-0674(98)80150-6

Stepanyuk GA, Serrano P, Peralta E, Farr CL, Axelrod HL, Geralt M, Das D, Chiu H-J, Jaroszewski L, Deacon $\mathrm{AM}$, et al. 2016. UHM-ULM interactions in the RBM39-U2AF65 splicing-factor complex. Acta Crystallogr D Biol Crystallogr 72: 497-511. doi:10.1107/ S2059798316001248

Stohr N, Buchmeier S, Kohn M, Lederer M, Baude A, Huttelmaier S, Wahle E, Weidensdorfer D, Schierhorn A. 2008. Control of c-myc mRNA stability by IGF2BP1-associated cytoplasmic RNPs. RNA 15: 104-115. doi:10 $.1261 /$ rna.1175909

Stoskus M, Gineikiene E, Valceckiene V, Valatkaite B, Pileckyte R, Griskevicius L. 2011. Identification of characteristic IGF2BP expression patterns in distinct B-ALL entities. Blood Cells Mol Dis 46: 321-326. doi:10.1016/ j.bcmd.2011.02.005

Strudwick S, Borden KLB. 2002. The emerging roles of translation factor eIF4E in the nucleus. Differentiation 70: 1022. doi:10.1046/j.1432-0436.2002.700102.x

Su R, Dong L, Li C, Nachtergaele S, Wunderlich M, Qing Y, Deng X, Wang Y, Weng X, Hu C, et al. 2018. R-2HG exhibits anti-tumor activity by targeting $\mathrm{FTO} / \mathrm{m}^{6} \mathrm{~A} /$ MYC/CEBPA signaling. Cell 172: 90-105.e23. doi:10 $.1016 /$ j.cell.2017.11.031

Supuran CT. 2003. Indisulam: An anticancer sulfonamide in clinical development. Expert Opin Investig Drugs 12: 283 287. doi:10.1517/13543784.12.2.283

Taggart J, Ho T, Amin E, Xu H, Barlowe TS, Perez AR, Durham BH, Tivnan P, Okabe R, Chow A, et al. 2016. MSI2 is required for maintaining activated myelodysplastic syndrome stem cells. Nat Commun 7: 10739. doi:10 $.1038 /$ ncomms 10739 
Tan K, Culjkovic B, Amri A, Borden KLB. 2008. Ribavirin targets eIF4E dependent Akt survival signaling. Biochem Biophys Res Commun 375: 341-345. doi:10.1016/j.bbrc 2008.07.163

Tang H, Wei Q, Ge J, Jian W, Liu J, Zhong L, Fu B, Zhao T. 2013. IMP3 as a supplemental diagnostic marker for Hodgkin lymphoma. Hum Pathol 44: 2167-2172. doi:10.1016/j.humpath.2013.04.011

Thol F, Winschel C, Sonntag A, Damm F, Wagner K, Chaturvedi A, Göhring G, Schlegelberger B, Lübbert M, Fiedler W, et al. 2013. Prognostic significance of expression levels of stem cell regulators MSI2 and NUMB in acute myeloid leukemia. Ann Hematol 92: 315-323. doi:10 .1007/s00277-012-1637-5

Tomimaru Y, Eguchi H, Wada H, Kobayashi S, Marubashi S, Tanemura M, Umeshita K, Kim T, Wakasa K, Doki Y, et al. 2012. IGFBP7 downregulation is associated with tumor progression and clinical outcome in hepatocellular carcinoma. Int J Cancer 130: 319-327. doi:10.1002/ijc .25994

Topisirovic I, Guzman ML, McConnell MJ, Licht JD, Culjkovic B, Neering SJ, Jordan CT, Borden KLB. 2003. Aberrant eukaryotic translation initiation factor $4 \mathrm{E}$-dependent mRNA transport impedes hematopoietic differentiation and contributes to leukemogenesis. Mol Cell Biol 23: 8992-9002. doi:10.1128/MCB.23.24.8992-9002 .2003

Topisirovic I, Siddiqui N, Borden KLB. 2009a. The eukaryotic translation initiation factor 4E (eIF4E) and HuR RNA operons collaboratively regulate the expression of survival and proliferative genes. Cell Cycle 8: 959-964. doi:10 $.4161 /$ cc.8.7.8093

Topisirovic I, Siddiqui N, Orolicki S, Skrabanek LA, Tremblay M, Hoang T, Borden KLB. 2009b. Stability of eukaryotic translation initiation factor $4 \mathrm{E} \mathrm{mRNA}$ is regulated by HuR, and this activity is dysregulated in cancer. Mol Cell Biol 29: 1152-1162. doi:10.1128/MCB.01532-08

Uehara T, Minoshima Y, Sagane K, Sugi NH, Mitsuhashi KO, Yamamoto N, Kamiyama H, Takahashi K, Kotake Y, Uesugi M, et al. 2017. Selective degradation of splicing factor CAPER $\alpha$ by anticancer sulfonamides. Nat Chem Biol 13: 675-680. doi:10.1038/nchembio. 2363

Uranishi H, Zolotukhin AS, Lindtner S, Warming S, Zhang G, Bear J, Copeland NG, Jenkins NA, Pavlakis GN, Felber BK. 2009. The RNA-binding motif protein 15B (RBM15B/OTT3) acts as cofactor of the nuclear export receptor NXF1. J Biol Chem 284: 26106-26116. doi:10.1074/jbc.M109.040113

Verhagen HJMP, De Leeuw DC, Roemer MGM, Denkers F, Pouwels W, Rutten A, Celie PH, Ossenkoppele GJ, Schuurhuis GJ, Smit L. 2014. IGFBP7 induces apoptosis of acute myeloid leukemia cells and synergizes with chemotherapy in suppression of leukemia cell survival. Cell Death Dis 5: e1300.

Verhagen HJMP, van Gils N, Martiañez T, van Rhenen A, Rutten A, Denkers F, de Leeuw DC, Smit MA, Tsui ML, de Vos Klootwijk LLE, et al. 2018. IGFBP7 induces differentiation and loss of survival of human acute myeloid leukemia stem cells without affecting normal hematopoiesis. Cell Rep 25: 3021-3035.e5. doi:10.1016/j.celrep.2018.11 .062
Visconte V, Makishima H, Jankowska A, Szpurka H, Traina F, Jerez A, O'Keefe C, Rogers HJ, Sekeres MA, Maciejewski JP, et al. 2012a. SF3B1, a splicing factor is frequently mutated in refractory anemia with ring sideroblasts. Leukemia 26: 542-545. doi:10.1038/leu.2011.232

Visconte V, Makishima H, Maciejewski JP, Tiu RV. 2012b. Emerging roles of the spliceosomal machinery in myelodysplastic syndromes and other hematological disorders. Leukemia 26: 2447-2454. doi:10.1038/leu.2012.130

Visconte V, Rogers HJ, Singh J, Barnard J, Bupathi M, Traina F, McMahon J, Makishima H, Szpurka H, Jankowska A, et al. 2012c. SF3B1 haploinsufficiency leads to formation of ring sideroblasts in myelodysplastic syndromes. Blood 120: 3173-3186. doi:10.1182/blood-2012-05-430876

Viswanathan SR, Powers JT, Einhorn W, Hoshida Y, Ng TL, Toffanin S, O'Sullivan M, Lu J, Phillips LA, Lockhart VL, et al. 2009. Lin 28 promotes transformation and is associated with advanced human malignancies. Nat Genet 41: 843-848. doi:10.1038/ng.392

Vu LP, Pickering BF, Cheng Y, Zaccara S, Nguyen D, Minuesa G, Chou T, Chow A, Saletore Y, MacKay M, et al. 2017a. The $N^{6}$-methyladenosine $\left(\mathrm{m}^{6} \mathrm{~A}\right)$-forming enzyme METTL3 controls myeloid differentiation of normal hematopoietic and leukemia cells. Nat Med 23: 1369-1376. doi:10.1038/nm.4416

Vu LP, Prieto C, Amin EM, Chhangawala S, Krivtsov A, Calvo-Vidal MN, Chou T, Chow A, Minuesa G, Park SM, et al. 2017b. Functional screen of MSI2 interactors identifies an essential role for SYNCRIP in myeloid leukemia stem cells. Nat Genet 49: 866-875. doi:10.1038/ng .3854

Vu LP, Cheng Y, Kharas MG. 2019. The biology of $\mathrm{m}^{6} \mathrm{~A}$ RNA methylation in normal and malignant hematopoiesis. Cancer Discov 9: 25-33. doi:10.1158/2159-8290.CD-180959

Wang HY, Xu X, Ding JH, Bermingham JR, Fu XD. 2001. SC35 plays a role in T cell development and alternative splicing of CD45. Mol Cell 7: 331-342. doi:10.1016/ S1097-2765(01)00181-2

Wang L, Lawrence MS, Wan Y, Stojanov P, Sougnez C, Stevenson K, Werner L, Sivachenko A, DeLuca DS, Zhang L, et al. 2011. SF3B1 and other novel cancer genes in chronic lymphocytic leukemia. N Engl J Med 365: 2497-2506. doi:10.1056/NEJMoa1109016

Wang K, Sanchez-Martin M, Wang X, Knapp KM, Koche R, Vu L, Nahas MK, He J, Hadler M, Stein EM, et al. 2017. Patient-derived xenotransplants can recapitulate the genetic driver landscape of acute leukemias. Leukemia 31: 151-158. doi:10.1038/leu.2016.166

Wang L, Rowe RG, Jaimes A, Yu C, Nam Y, Pearson DS, Zhang J, Xie X, Marion W, Heffron GJ, et al. 2018. Smallmolecule inhibitors disrupt let-7 oligouridylation and release the selective blockade of let-7 processing by LIN28. Cell Rep 23: 3091-3101. doi:10.1016/j.celrep.2018.04.116

Wang E, Lu SX, Pastore A, Chen X, Imig J, Chun-Wei Lee S, Hockemeyer K, Ghebrechristos YE, Yoshimi A, Inoue D, et al. 2019. Targeting an RNA-binding protein network in acute myeloid leukemia. Cancer Cell 35: 369-384.e7. doi:10.1016/j.ccell.2019.01.010

Wendel H-G, De Stanchina E, Fridman JS, Malina A, Ray S, Kogan S, Cordon-Cardo C, Pelletier J, Lowe SW. 2004. Survival signalling by Akt and eIF4E in oncogenesis and 
cancer therapy. Nature 428: 332-337. doi:10.1038/na ture 02369

Weng H, Huang H, Wu H, Qin X, Zhao BS, Dong L, Shi H, Skibbe J, Shen C, Hu C, et al. 2018. METTL14 inhibits hematopoietic stem/progenitor differentiation and promotes leukemogenesis via mRNA $\mathrm{m}^{6} \mathrm{~A}$ modification. Cell Stem Cell 22: 191-205.e9. doi:10.1016/j.stem.2017 .11 .016

Wiellette EL, Harding KW, Mace KA, Ronshaugen MR Wang FY, Mcginnis W. 1999. spen encodes an RNP motif protein that interacts with Hox pathways to repress the development of head-like sclerites in the Drosophila trunk. Development 126: 5373-5385.

Wolfe AL, Singh K, Zhong Y, Drewe P, Rajasekhar VK, Sanghvi VR, Mavrakis KJ, Jiang M, Roderick JE, Van der Meulen J, et al. 2014. RNA G-quadruplexes cause eIF4A-dependent oncogene translation in cancer. Nature 513: 65-70. doi:10.1038/nature13485

Wurth L, Gebauer F. 2015. RNA-binding proteins, multifaceted translational regulators in cancer. Biochim Biophys Acta 1849: 881-886. doi:10.1016/j.bbagrm.2014.10.001

Xing L, Yao X, Williams KR, Bassell GJ. 2012. Negative regulation of RhoA translation and signaling by hnRNPQ1 affects cellular morphogenesis. Mol Biol Cell 23: 15001509. doi:10.1091/mbc.e11-10-0867

Yilmaz H, Valdez R, Theisen BK, Guo W, Ferguson DO, Wu H, Morrison SJ. 2006. Pten dependence distinguishes haematopoietic stem cells from leukaemia-initiating cells. Nature 441: 475-482. doi:10.1038/nature04703

Yoshida K, Sanada M, Shiraishi Y, Nowak D, Nagata Y, Yamamoto R, Sato Y, Sato-Otsubo A, Kon A, Nagasaki M, et al. 2011. Frequent pathway mutations of splicing
RNA Regulators in Leukemia and Lymphoma

machinery in myelodysplasia. Nature 478: 64-69. doi:10 $.1038 /$ nature 10496

Yu J, Vodyanik MA, Smuga-Otto K, Antosiewicz-Bourget J, Frane JL, Tian S, Nie J, Jonsdottir GA, Ruotti V, Stewart R, et al. 2007. Induced pluripotent stem cell lines derived from human somatic cells. Science 318: 1917-1920. doi:10.1126/science.1151526

Zheng G, Dahl JA, Niu Y, Fedorcsak P, Huang CM, Li CJ, Vågbø $\mathrm{CB}$, Shi $\mathrm{Y}$, Wang WL, Song SH, et al. 2013. ALKBH5 is a mammalian RNA demethylase that impacts RNA metabolism and mouse fertility. Mol Cell 49: 18-29. doi:10.1016/j.molcel.2012.10.015

Zhou J, Bi C, Ching YQ, Chooi J, Lu X, Quah JY, Toh SH, Chan Z, Tan TZ, Chong PSY, et al. 2017a. Inhibition of LIN28B impairs leukemia cell growth and metabolism in acute myeloid leukemia. J Hematol Oncol 10: 138. doi:10 .1186/s13045-017-0507-y

Zhou J, Chan ZL, Bi C, Lu X, Chong PSY, Chooi JY, Cheong LL, Liu SC, Ching YQ, Zhou Y, et al. 2017b. LIN28B activation by PRL-3 promotes leukemogenesis and a stem cell-like transcriptional program in AML. Mol Cancer Res 15: 294-303. doi:10.1158/1541-7786.MCR-160275-T

Zhu H, Shah S, Shyh-Chang N, Shinoda G, Einhorn WS, Viswanathan SR, Takeuchi A, Grasemann C, Rinn JL, Lopez MF, et al. 2010. Lin28a transgenic mice manifest size and puberty phenotypes identified in human genetic association studies. Nat Genet 42: 626-630. doi:10.1038/ ng.593

Zolotukhin AS, Uranishi H, Lindtner S, Bear J, Pavlakis GN, Felber BK. 2009. Nuclear export factor RBM15 facilitates the access of DBP5 to mRNA. Nucleic Acids Res 37: 71517162. doi:10.1093/nar/gkp782 


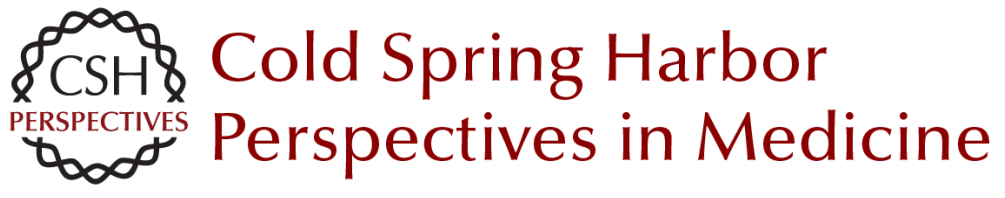

\section{RNA Regulators in Leukemia and Lymphoma}

Camila Prieto and Michael G. Kharas

Cold Spring Harb Perspect Med 2020; doi: 10.1101/cshperspect.a034967 originally published online October 15, 2019

\section{Subject Collection Leukemia and Lymphoma: Molecular and Therapeutic Insights}

Oncogenic Mechanisms and Therapeutic Targeting of Metabolism in Leukemia and Lymphoma

Maximilian Stahl, Zachary D. Epstein-Peterson and Andrew M. Intlekofer

Non-Hodgkin Lymphomas: Malignancies Arising from Mature B Cells Jennifer Shingleton, Jie Wang, Carolyn Baloh, et al.

MAP-Kinase-Driven Hematopoietic Neoplasms: A Decade of Progress in the Molecular Age Rikhia Chakraborty, Omar Abdel-Wahab and Benjamin H. Durham

Mouse Models in the Study of Mature B-Cell Malignancies Laura Pasqualucci and Ulf Klein

Mouse Models of Myeloid Malignancies Faisal Basheer and George Vassiliou

Epigenetic Mechanisms in Leukemias and Lymphomas

Cihangir Duy, Wendy Béguelin and Ari Melnick

The Biology of B-Progenitor Acute Lymphoblastic Leukemia

Kathryn G. Roberts and Charles G. Mullighan

RNA Regulators in Leukemia and Lymphoma Camila Prieto and Michael G. Kharas
Biological and Translational Considerations regarding the Recent Therapeutic Successes and Upcoming Challenges for Multiple Myeloma Constantine S. Mitsiades

Biology and Molecular Pathogenesis of Mature T-Cell Lymphomas José R. Cortés and Teresa Palomero

The Role of Somatic Mutations in Acute Myeloid Leukemia Pathogenesis Ashwin Kishtagari and Ross L. Levine

Chronic Lymphocytic Leukemia Nicholas Chiorazzi, Shih-Shih Chen and Kanti R. Rai

Normal Hematopoiesis Is a Balancing Act of

Self-Renewal and Regeneration Oakley C. Olson, Yoon-A Kang and Emmanuelle Passegué

Impact of Genetics on Mature Lymphoid

Leukemias and Lymphomas

Nathanael G. Bailey and Kojo S.J. Elenitoba-Johnson

Epidemiology and Etiology of Leukemia and

Lymphoma Jordan A. Baeker Bispo, Paulo S. Pinheiro and Erin K. Kobetz

Clonal Hematopoiesis and Premalignant Diseases Justin Kaner, Pinkal Desai, Nuria Mencia-Trinchant, et al.

For additional articles in this collection, see http://perspectivesinmedicine.cshlp.org/cgi/collection/ 